\title{
Separation and Identification of Antioxidants and Aldose Reductase Inhibitors in Lepechinia meyenii (Walp.) Epling
}

\author{
Guanglei Zuo ${ }^{1}{ }^{(}$, Kang-Hoon Je ${ }^{2}$, Yanymee N. Guillen Quispe ${ }^{3}{ }^{\circledR}$, Kyong-Oh Shin ${ }^{1}$, Hyun Yong Kim ${ }^{1}$, \\ Kang Hyuk Kim ${ }^{1}$, Paul H. Gonzales Arce ${ }^{4}$ and Soon Sung Lim $1,2,5, * \mathbb{D}$ \\ 1 Department of Food Science and Nutrition, Hallym University, 1 Hallymdeahak-gil, \\ Chuncheon 24252, Korea; guangleizuo@foxmail.com (G.Z.); tlsruddhek@hallym.ac.kr (K.-O.S.); \\ khy9514@nate.com (H.Y.K.); M20023@hallym.ac.kr (K.H.K.) \\ 2 Institute of Korean Nutrition, Hallym University, 1 Hallymdeahak-gil, Chuncheon 24252, Korea; \\ jekh@hallym.ac.kr \\ 3 Department of Molecular Medicine and Biopharmaceutical Sciences, Graduate School of Convergence \\ Science and Technology, Seoul National University, Seoul 151742, Korea; yany24@snu.ac.kr \\ 4 Laboratorio de Florística, Departamento de Dicotiledóneas, Museo de Historia Natural—Universidad \\ Nacional Mayor de San Marcos, Avenida Arenales 1256, Lima 14-0434, Peru; pgonzalesarce@hotmail.com \\ 5 Institute of Natural Medicine, Hallym University, 1 Hallymdeahak-gil, Chuncheon 24252, Korea \\ * Correspondence: limss@hallym.ac.kr; Tel.: +82-33-248-2133; Fax: +82-33-256-3420
}

\section{check for} updates

Citation: Zuo, G.; Je, K.-H.; Guillen Quispe, Y.N.; Shin, K.-O.; Kim, H.Y.; Kim, K.H.; Arce, P.H.G.; Lim, S.S. Separation and Identification of Antioxidants and Aldose Reductase Inhibitors in Lepechinia meyenii (Walp.) Epling. Plants 2021, 10, 2773. https://doi.org/10.3390/ plants10122773

Academic Editors: Simon Vlad Luca, Adriana Trifan and Gokhan Zengin

Received: 25 November 2021 Accepted: 10 December 2021 Published: 15 December 2021

Publisher's Note: MDPI stays neutral with regard to jurisdictional claims in published maps and institutional affiliations.

Copyright: (c) 2021 by the authors. Licensee MDPI, Basel, Switzerland. This article is an open access article distributed under the terms and conditions of the Creative Commons Attribution (CC BY) license (https:/ / creativecommons.org/licenses/by/ $4.0 /)$.

\begin{abstract}
We previously reported that Lepechinia meyenii (Walp.) Epling has antioxidant and aldose reductase (AR) inhibitory activities. In this study, L. meyenii was extracted in a $50 \% \mathrm{MeOH}$ and $\mathrm{CH}_{2} \mathrm{Cl}_{2} / \mathrm{MeOH}$ system. The active extracts of $\mathrm{MeOH}$ and $50 \% \mathrm{MeOH}$ were subjected to fractionation, followed by separation using high-speed counter-current chromatography (HSCCC) and preparative HPLC. Separation and identification revealed the presence of caffeic acid, hesperidin, rosmarinic acid, diosmin, methyl rosmarinate, diosmetin, and butyl rosmarinate. Of these, rosmarinic acid, methyl rosmarinate, and butyl rosmarinate possessed remarkable antioxidant and AR inhibitory activities. The other compounds were less active. In particular, rosmarinic acid is the key contributor to the antioxidant and AR inhibitory activities of L. meyenii; it is rich in the $\mathrm{MeOH}$ extract $(333.84 \mathrm{mg} / \mathrm{g}$ ) and $50 \% \mathrm{MeOH}$ extract $(135.41 \mathrm{mg} / \mathrm{g}$ ) of L. meyenii and is especially abundant in the EtOAc and $n$ - $\mathrm{BuOH}$ fractions (373.71-804.07 $\mathrm{mg} / \mathrm{g}$ ) of the $\mathrm{MeOH}$ and $50 \% \mathrm{MeOH}$ extracts. The results clarified the basis of antioxidant and AR inhibitory activity of L. meyenii, adding scientific evidence supporting its traditional use as an anti-diabetic herbal medicine. The HSCCC separation method established in this study can be used for the preparative separation of rosmarinic acid from natural products.
\end{abstract}

Keywords: Lepechinia meyenii (Walp.) Epling; antioxidant; aldose reductase inhibitor; high-speed counter-current chromatography; rosmarinic acid; quantification

\section{Introduction}

Diabetes mellitus, characterized by hyperglycemia and diabetic complications, is one of the most common chronic degenerative diseases worldwide, with nearly 463 million cases reported in 2019 alone [1]. Multi-therapeutical strategies beyond glycemic control are required to treat diabetes and its complications. Among these, aldose reductase (AR) and oxidative stress are considered significant therapeutic targets [2,3]. AR is the key enzyme in the polyol pathway that catalyzes NADPH-dependent reduction of glucose to sorbitol [3]. In hyperglycemic conditions, AR is activated and the polyol pathway flux is increased; it causes depletion of NADPH and overproduction of sorbitol, leading to cellular oxidative stress and sorbitol-induced osmotic stress, which are implicated in diabetic complications in insulin-independent tissues, including kidney, lens, retina, and neural tissues [3,4]. Moreover, reactive oxygen species (ROS) and the resulting oxidative stress are key contributors to diabetic complications $[5,6]$. Therefore, inhibition of AR and ROS/oxidative stress is considered a therapeutic target for treating diabetic complications $[2,3]$. 
Natural products are important resources of anti-diabetic agents, among which herb medicines play a significant role. Lepechinia meyenii (Walp.) Epling (L. meyenii), belonging to the Lamiaceae family, is native to Argentina, Bolivia, and Peru [7]. The infusion of L. meyenii is used as a traditional herb medicine in Peru to treat diabetes, cough, inflammation, diarrhea, spasm, burning sensation in the stomach, and pain in the stomach and joints [8-10]. In our ongoing research to screen and isolate potential anti-diabetic agents from natural products [11-14], we found that the 70\% MeOH extract of L. meyenii has strong antioxidant and AR inhibitory activities [15], indicating the presence of potent antioxidants and AR inhibitors in this plant. Many diterpenoids have been previously identified from L. meyenii. Recently, it has been reported to have antibacterial and tyrosinase inhibitory activities; therefore, carnosol, rosmanol, carnosic acid, $p$-coumaric acid, caffeic acid, and rosmarinic acid were isolated and identified [16,17]. Nevertheless, the antioxidant and AR inhibitory compounds in L. meyenii remain unidentified, which prompted us to separate and identify the underlying bioactive compounds from this plant.

High-speed counter-current chromatography (HSCCC) is a liquid-liquid partitionbased chromatography widely used in separating natural products [18-21]. It has advantages of solid support-free, high sample-loading capacity, no irreversible adsorption, and low risk of sample denaturation [22], and, therefore, was used for preparative separation of the antioxidants and AR inhibitors from L. meyenii in this study. Samples with simple component composition and low quantity were separated using preparative HPLC (pre-HPLC). Moreover, because rosmarinic acid, methyl rosmarinate, and butyl rosmarinate separated from L. meyenii in this study possessed remarkable antioxidant and AR inhibitory activities, ethyl and propyl rosmarinates were further synthesized to study the esterification effects of rosmarinic acid using short-chain primary alcohol $(\leq \mathrm{C} 4)$ on its antioxidant and AR inhibitory activities.

Therefore, we aimed to separate and identify the antioxidants and AR inhibitors in L. meyenii. In addition, the esterification effects of rosmarinic acid on its antioxidant and AR inhibitory activities using short-chain primary alcohols $(\leq C 4)$ were examined, and the major compound, rosmarinic acid, was quantified in all the extracts and fractions of L. meyenii.

\section{Results}

\subsection{Antioxidant, AR Inhibition, and HPLC Profile of the Extracts and Fractions of L. meyenii}

Previously we found that the $70 \% \mathrm{MeOH}$ extract of L. meyenii exhibited strong DPPH radical scavenging activity and $\mathrm{AR}$ inhibitory activity [15]. In order to discover the active components in L. meyenii, the activities of the $\mathrm{CH}_{2} \mathrm{Cl}_{2}, \mathrm{MeOH}$, and $50 \% \mathrm{MeOH}$ extracts of L. meyenii against DPPH radicals and AR were comparatively determined using quercetin as a positive control $[23,24]$. As shown in Table 1 , both the antioxidant and AR inhibitory activities of the $\mathrm{MeOH}$ extract (DPPH, $\mathrm{IC}_{50} 32.81 \mu \mathrm{g} / \mathrm{mL} ; \mathrm{AR}, \mathrm{IC}_{50} 1.64 \mu \mathrm{g} / \mathrm{mL}$ ) and the $50 \% \mathrm{MeOH}$ extract (DPPH, $\mathrm{IC}_{50} 34.04 \mu \mathrm{g} / \mathrm{mL}$; AR, IC $504.02 \mu \mathrm{g} / \mathrm{mL}$ ) were significantly higher than those of the $\mathrm{CH}_{2} \mathrm{Cl}_{2}$ extract (DPPH, $16.54 \%$ inhibition at $40 \mu \mathrm{g} / \mathrm{mL} ; \mathrm{AR}$, $11.8 \%$ inhibition at $10 \mu \mathrm{g} / \mathrm{mL}$ ). Moreover, the $\mathrm{MeOH}$ extract and the $50 \% \mathrm{MeOH}$ extract showed higher AR inhibitory activity than quercetin $\left(\mathrm{IC}_{50} 4.34 \mu \mathrm{g} / \mathrm{mL}\right)$ and lower DPPH scavenging activity than quercetin $\left(\mathrm{IC}_{50} 10.46 \mu \mathrm{g} / \mathrm{mL}\right)$. The HPLC profile of the extracts suggested that the antioxidant and AR inhibitory activities of the $\mathrm{MeOH}$ extract and the $50 \% \mathrm{MeOH}$ extract were mainly due to one major compound (Figure 1).

Then, the $\mathrm{MeOH}$ extract and the $50 \% \mathrm{MeOH}$ extract were further partitioned using $\mathrm{H}_{2} \mathrm{Cl}_{2}$, EtOAc, $n-\mathrm{BuOH}$, and water and subjected to activity assay (Table 1 ). Among these fractions, the EtOAc fraction of the $50 \% \mathrm{MeOH}$ extract showed the highest DPPH scavenging activity ( $\left.\mathrm{IC}_{50} 14.81 \mu \mathrm{g} / \mathrm{mL}\right)$ and $\mathrm{AR}$ inhibitory activity $\left(\mathrm{IC}_{50}, 0.86 \mu \mathrm{g} / \mathrm{mL}\right)$, followed by the EtOAc fraction of the MeOH extract (DPPH, $\mathrm{IC}_{50} 15.48 \mu \mathrm{g} / \mathrm{mL} ; \mathrm{AR}, 1.24 \mu \mathrm{g} / \mathrm{mL}$ ), the $n-\mathrm{BuOH}$ fraction of the $50 \% \mathrm{MeOH}\left(\mathrm{DPPH}, \mathrm{IC}_{50} 26.20 \mu \mathrm{g} / \mathrm{mL}\right.$; AR, $\left.1.23 \mu \mathrm{g} / \mathrm{mL}\right)$, and the $n-\mathrm{BuOH}$ fraction of the $\mathrm{MeOH}$ extract (DPPH, IC $5031.54 \mu \mathrm{g} / \mathrm{mL} ; \mathrm{AR}, 1.94 \mu \mathrm{g} / \mathrm{mL}$ ), all of which exhibited significantly higher AR inhibitory activity than quercetin $\left(\mathrm{IC}_{50}\right.$ 
$4.34 \mu \mathrm{g} / \mathrm{mL}$ ), indicating that strong AR inhibitors exist in these fractions. Moreover, potent antioxidants may also exist in these fractions despite their DPPH scavenging activities being lower than those of quercetin $\left(\mathrm{IC}_{50} 10.46 \mu \mathrm{g} / \mathrm{mL}\right.$ ). Further HPLC profiles of the fractions and the white-color precipitate produced during the partition process of the $\mathrm{MeOH}$ extract revealed more components in addition to the major one (Figure 2). To better understand the component composition and discover highly active antioxidants and AR inhibitors, the minor compounds 1, 2, 4-7, together with the major compound 3, were selected as the target compounds to be separated (Figure 2).

Table 1. Antioxidant and aldose reductase (AR) inhibitory activity of the extracts and fractions of L. meyenii.

\begin{tabular}{|c|c|c|c|c|c|c|}
\hline \multirow[b]{2}{*}{ Sample } & \multicolumn{3}{|c|}{ DPPH Scavenging Activity } & \multicolumn{3}{|c|}{ AR Inhibitory Activity (\%) } \\
\hline & $\begin{array}{c}\text { Concentration } \\
(\mu \mathrm{g} / \mathrm{mL})\end{array}$ & Inhibition (\%) & $\mathrm{IC}_{50}(\mu \mathrm{g} / \mathrm{mL})$ & $\begin{array}{c}\text { Concentration } \\
(\mu \mathrm{g} / \mathrm{mL})\end{array}$ & Inhibition (\%) & $\mathrm{IC}_{50}(\mu \mathrm{g} / \mathrm{mL})$ \\
\hline \multirow{4}{*}{$\mathrm{CH}_{2} \mathrm{Cl}_{2}$ extract } & 40 & $16.54 \pm 1.16$ & & 10 & $11.08 \pm 0.62$ & \\
\hline & 20 & $8.92 \pm 1.00$ & - & 5 & $7.81 \pm 0.40$ & - \\
\hline & 10 & $2.80 \pm 0.13$ & & 2.5 & $5.79 \pm 0.53$ & \\
\hline & 40 & $60.61 \pm 3.42$ & & 2.5 & $62.16 \pm 2.38$ & \\
\hline \multirow[t]{3}{*}{$\mathrm{MeOH}$ extract } & 20 & $31.22 \pm 0.89$ & $32.81 \pm 1.35^{\mathrm{ab}}$ & 1.25 & $41.67 \pm 1.32$ & $1.64 \pm 0.10^{\mathrm{e}}$ \\
\hline & 10 & $16.46 \pm 0.55$ & & 0.625 & $23.48 \pm 0.22$ & \\
\hline & 40 & $19.78 \pm 0.69$ & & 10 & $57.49 \pm 4.88$ & \\
\hline \multirow[t]{3}{*}{$\mathrm{MeE} \mathrm{CH}_{2} \mathrm{Cl}_{2}$ fr. } & 20 & $11.73 \pm 0.33$ & - & 5 & $30.06 \pm 0.66$ & $8.34 \pm 0.94^{\mathrm{a}}$ \\
\hline & 10 & $5.91 \pm 0.76$ & & 2.5 & $15.26 \pm 1.32$ & \\
\hline & 20 & $61.44 \pm 0.49$ & & 2.5 & $70.09 \pm 1.55$ & \\
\hline \multirow[t]{3}{*}{ MeE EtOAc fr. } & 10 & $37.60 \pm 0.89$ & $15.48 \pm 0.04^{\mathrm{d}}$ & 1.25 & $50.50 \pm 0.45$ & $1.24 \pm 0.06^{\mathrm{e}}$ \\
\hline & 5 & $18.31 \pm 0.57$ & & 0.625 & $30.15 \pm 1.98$ & \\
\hline & 40 & $62.80 \pm 0.92$ & & 5 & $68.80 \pm 0.45$ & \\
\hline \multirow[t]{3}{*}{ MeE BuOH fr. } & 20 & $32.38 \pm 1.48$ & $31.54 \pm 1.00^{\mathrm{b}}$ & 2.5 & $54.21 \pm 0.23$ & $1.94 \pm 0.24^{\mathrm{d}}$ \\
\hline & 10 & $17.72 \pm 0.28$ & & 1.25 & $41.67 \pm 4.74$ & \\
\hline & 40 & $36.49 \pm 0.55$ & & 10 & $68.57 \pm 5.14$ & \\
\hline \multirow[t]{2}{*}{ MeE water fr. } & 20 & $20.43 \pm 0.84$ & - & 5 & $48.39 \pm 1.98$ & $5.35 \pm 0.49^{b}$ \\
\hline & 10 & $10.52 \pm 0.37$ & & 2.5 & $28.13 \pm 0.45$ & \\
\hline \multirow{3}{*}{$\begin{array}{c}50 \% \mathrm{MeOH} \\
\text { extract }\end{array}$} & 40 & $57.89 \pm 1.75$ & & 5 & $56.32 \pm 0.93$ & \\
\hline & 20 & $31.67 \pm 0.84$ & $34.04 \pm 0.89^{\mathrm{a}}$ & 2.5 & $36.26 \pm 1.54$ & $4.02 \pm 0.17^{c}$ \\
\hline & 10 & $15.08 \pm 1.06$ & & 1.25 & $20.73 \pm 1.14$ & \\
\hline \multirow{3}{*}{$\begin{array}{l}50 \% \mathrm{MeE} \\
\mathrm{CH}_{2} \mathrm{Cl}_{2} \text { fr. }\end{array}$} & 40 & $26.51 \pm 1.02$ & & 10 & $67.57 \pm 0.81$ & \\
\hline & 20 & $13.23 \pm 1.09$ & - & 5 & $49.59 \pm 0.83$ & $5.05 \pm 0.12 b c$ \\
\hline & 10 & $7.94 \pm 0.53$ & & 2.5 & $32.05 \pm 1.7$ & \\
\hline \multirow{3}{*}{$\begin{array}{l}50 \% \mathrm{MeE} \\
\text { EtOAc fr. }\end{array}$} & 20 & $65.12 \pm 0.90$ & & 2.5 & $75.03 \pm 0.88$ & \\
\hline & 10 & $37.18 \pm 0.38$ & $14.81 \pm 0.14^{\mathrm{d}}$ & 1.25 & $58.77 \pm 1.32$ & $0.86 \pm 0.07^{\mathrm{e}}$ \\
\hline & 5 & $18.73 \pm 0.89$ & & 0.625 & $42.28 \pm 2.41$ & \\
\hline \multirow{3}{*}{$\begin{array}{l}50 \% \mathrm{MeE} \\
\mathrm{BuOH} \text { fr. }\end{array}$} & 40 & $74.23 \pm 3.16$ & & 2.5 & $62.72 \pm 1.32$ & \\
\hline & 20 & $40.76 \pm 0.46$ & $26.20 \pm 0.70^{c}$ & 1.25 & $53.16 \pm 0.55$ & $1.23 \pm 0.02^{\mathrm{e}}$ \\
\hline & 10 & $21.16 \pm 0.16$ & & 0.625 & $35.00 \pm 0.66$ & \\
\hline \multirow{3}{*}{$\begin{array}{c}50 \% \mathrm{MeE} \\
\text { water fr. }\end{array}$} & 40 & $36.57 \pm 0.65$ & & 10 & $47.81 \pm 2.01$ & \\
\hline & 20 & $20.26 \pm 0.56$ & - & 5 & $24.65 \pm 0.46$ & - \\
\hline & 10 & $8.91 \pm 0.75$ & & 2.5 & $12.34 \pm 0.45$ & \\
\hline \multirow{3}{*}{ Quercetin } & 20 & $84.78 \pm 2.36$ & & 10 & $64.04 \pm 0.88$ & \\
\hline & 10 & $54.43 \pm 2.07$ & $10.46 \pm 0.34^{\mathrm{e}}$ & 5 & $55.26 \pm 1.58$ & $4.34 \pm 0.06^{b c}$ \\
\hline & 5 & $28.65 \pm 0.38$ & & 2.5 & $38.74 \pm 0.91$ & \\
\hline
\end{tabular}

Note: "MeE", “50\% MeE", and "fr." are the abbreviations of "MeOH extract", “50\% MeOH extract", and "fraction", respectively. Quercetin was used as a positive control. Different superscript letters (a,b,c,d,e $)$ in each $\mathrm{IC}_{50}$ column indicate significant differences $(p<0.05)$, and "_" means the $\mathrm{IC}_{50}$ values were not available within the concentrations tested. 


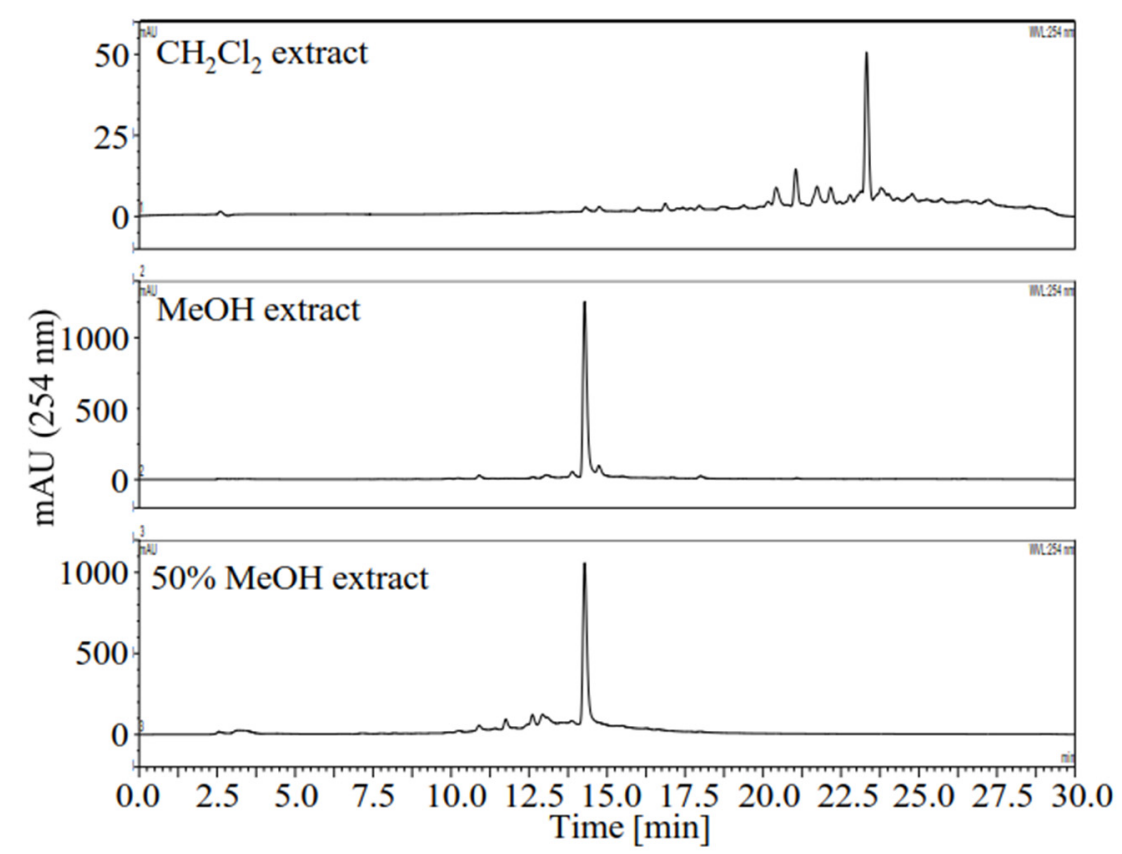

Figure 1. HPLC profiles of the extracts of Lepechinia meyenii (Walp.) Epling. The major compound in the $\mathrm{MeOH}$ and $50 \% \mathrm{MeOH}$ extracts was later identified as rosmarinic acid.
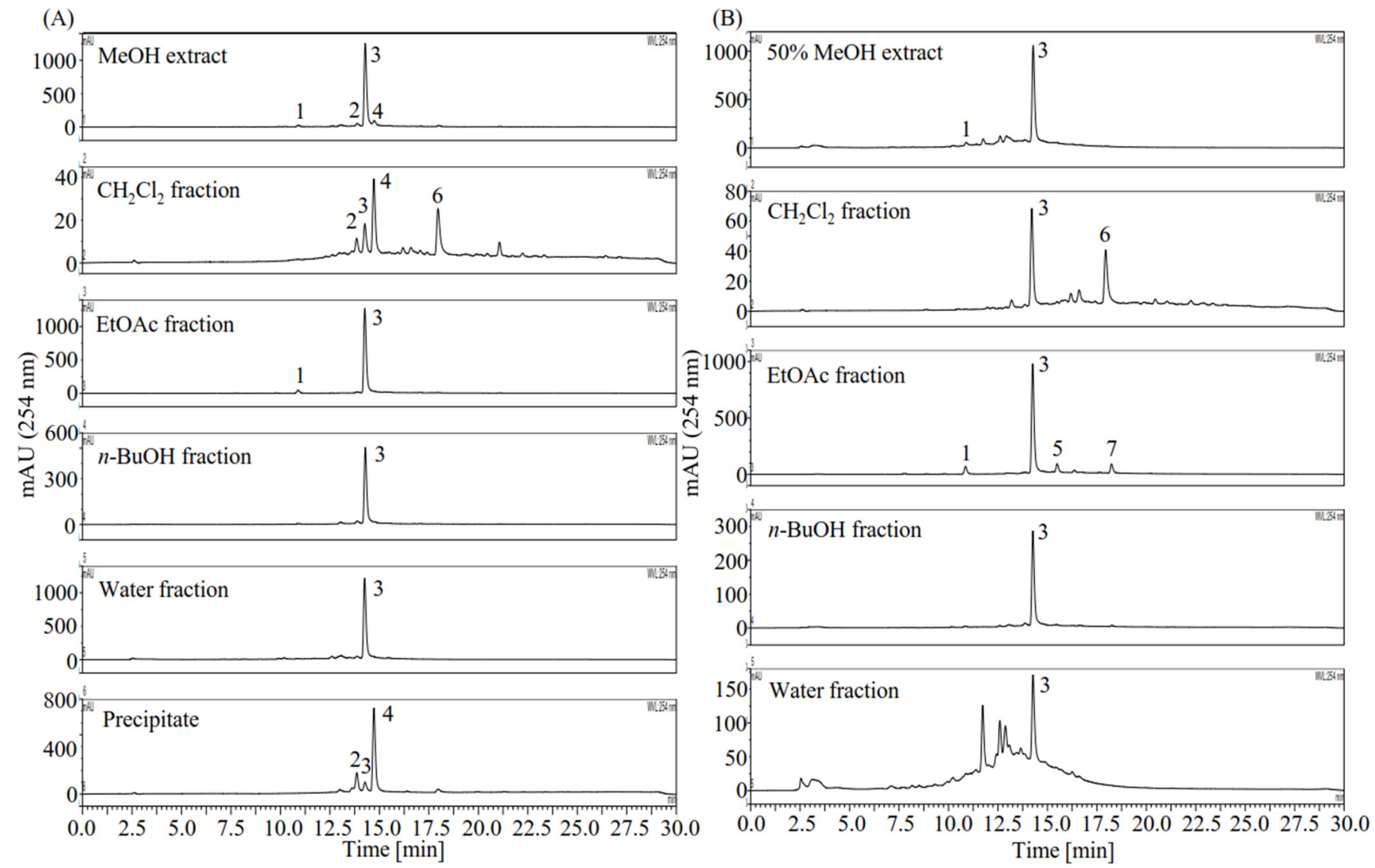

Figure 2. HPLC profiles of the fractions from the $\mathrm{MeOH}$ and the $50 \% \mathrm{MeOH}$ extracts of Lepechinia meyenii (Walp.) Epling. (A) HPLC profiles of the MeOH extract and its partitioned fractions and precipitate. (B) HPLC profiles of the $50 \% \mathrm{MeOH}$ extract and its partitioned fractions. The precipitate in (A) was produced during the partition process of the $\mathrm{MeOH}$ extract. Notably, compounds 1-7 were later identified as caffeic acid (1), hesperidin (2), rosmarinic acid (3), diosmin (4), methyl rosmarinate (5), diosmetin (6), and butyl rosmarinate (7). 


\subsection{Separation of the Phytochemicals in the Active Fractions of L. meyenii}

2.2.1. Separation of Components from the EtOAc Fraction of 50\% MeOH Extract by HSCCC

Selection of a suitable solvent system plays a pivotal role to achieve a successful HSCCC separation and an ideal solvent system usually offers a partition coefficient $(K)$ within 0.5 and $2.0(0.5 \leq K \leq 2.0)$ and a separation factor $(\alpha)$ more than $1.5(\alpha \geq 1.5$; $\alpha=K_{1} / K_{2}, K_{1} \geq K_{2}$ ) [22]. Accordingly, suitable $K$ values were obtained from $n$-hexane/ EtOAc/MeOH/water $(2: 5: 2: 5, v / v)$ for compounds 1 and $3\left(K_{1}=1.16, K_{3}=0.90\right)$; from $n$-hexane/EtOAc/MeOH/water $(3: 5: 3: 5, v / v)$ for compound $5(K=0.67)$; and from $n$-hexane/EtOAc/MeOH/water (4:5:4:5, $v / v)$ for compound $7(K=0.68)$ (Table 2). However, compounds 1 and 3 exhibited a small $\alpha$ value $\left(\alpha_{K 1 / K 3}=1.29\right)$ using $n$-hexane/EtOAc/ $\mathrm{MeOH} /$ water $(2: 5: 2: 5, v / v)$. Subsequently, modification of the solvent system by adding acid, a widely used strategy for HSCCC separation [22,25], was performed by adding acetic acid $(0.1 \%, v / v)$ to the solvent system $n$-hexane/EtOAc/MeOH/water $(2: 5: 2: 5, v / v)$. However, this did not improve the $\alpha$ value of compounds 1 and $3\left(\alpha_{K 1 / K 3}=1.27\right)$.

Table 2. Screening of the HSCCC solvent system.

\begin{tabular}{|c|c|c|c|c|c|}
\hline \multirow{2}{*}{$\begin{array}{c}\text { Solvent Systems } \\
n \text {-Hexane/EtOAc/MeOH/Water (v/v) }\end{array}$} & \multicolumn{4}{|c|}{$K$ Values of Compounds $1,3,5,7$} & \multirow{2}{*}{$\alpha_{K 1 / K 3}$} \\
\hline & 1 & 3 & 5 & 7 & \\
\hline $4: 5: 4: 5$ & 0.12 & 0.06 & 0.15 & 0.68 & 2.00 \\
\hline 3:5:3:5 & 0.37 & 0.32 & 0.67 & 2.64 & 1.16 \\
\hline $2: 5: 2: 5$ & 1.16 & 0.90 & 2.59 & 7.89 & 1.29 \\
\hline $1: 5: 1: 5$ & 4.94 & 3.45 & 10.10 & 56.98 & 1.43 \\
\hline $2: 5: 2: 5+0.1 \%$ acetic acid & 1.14 & 0.89 & 2.62 & 8.66 & 1.27 \\
\hline
\end{tabular}

In addition to modification by adding acid, modification of solvent systems by adding $\mathrm{MeOH}$ has been recently proved to be a promising strategy for HSCCC separation [26,27], and was thus applied to modify the solvent system $n$-hexane/EtOAc/MeOH/water $(2: 5: 2: 5, v / v)$ in this study. Briefly, PL, the lower layer of $n$-hexane/EtOAc/MeOH/water $(2: 5: 2: 5, v / v)$, was modified by adding extra volume of $10 \%, 20 \%$, and $40 \% \mathrm{MeOH}$. The MeOH-modified PLs were then individually paired with PU, the upper layer of $n$-hexane/EtOAc/MeOH/water (2:5:2:5, $v / v)$, to form new solvent systems. As shown in Table 3, suitable $K$ values of compounds $\mathbf{1}, 3$ and $\mathbf{5}$ were achieved $\left(K_{1}=0.85, K_{3}=0.58\right.$, $K_{5}=1.42$ ) by the new solvent system paired by equal volumes of PU and PL $+10 \% \mathrm{MeOH}$ $(v / v)$, and the $\alpha$ value between compounds 1 and 3 increased to $1.47\left(K_{1} / K_{3}\right)$. With $40 \%$ $\mathrm{MeOH}$ added to PL $(v / v)$, resulting in the new solvent system, paired with an equal volume of PU and PL $+40 \% \mathrm{MeOH}(v / v)$, the $K$ value of compound 4 decreased to 0.67 . A polarity-gradient elution HSCCC separation strategy was thus proposed by using PU as the stationary phase, whereas PL $+10 \% \mathrm{MeOH}(v / v)$ was selected as the first mobile phase to separate components 1, 3, and 5, and $\mathrm{PL}+40 \% \mathrm{MeOH}(v / v)$ was selected as the second mobile phase to separate component 7.

Separation using a polarity-gradient elution HSCCC strategy was carried out as described in Section 4.3. Briefly, the EtOAc fraction of the $50 \% \mathrm{MeOH}$ extract (1.37 g) was first eluted using $\mathrm{PL}+10 \% \mathrm{MeOH}(v / v)$ (the first mobile phase), isolating a single compound $5(31.3 \mathrm{mg})$ and a mixture of components $\mathbf{1}, \mathbf{3}$, and $5(846.1 \mathrm{mg})$ and further eluted using $\mathrm{PL}+40 \% \mathrm{MeOH}(v / v)$ (the second mobile phase) yielding compound 7 (33.0 mg) (Figure 3A,B). A severe loss of the stationary phase, a common problem in polarity-gradient elution HSCCC separation, as mentioned by [28], also occurred in this study, resulting in a retention rate of the stationary phase of only $20 \%$. The purities of compounds 5 and 7, determined by HPLC at $254 \mathrm{~nm}$, were $89 \%$ and $95 \%$, respectively. However, it failed to separate compounds $\mathbf{1}$ and $\mathbf{3}$ despite their $\alpha$ value being acceptable $\left(\alpha_{K 1} / K_{2}=1.47\right)$. The reason for the failure to separate compounds 1 and 3 may be the poor stationary phase volume retention ratio (20\%) [22] and overloading of the sample (1.37 g), particularly the major compound $\mathbf{3}$, because the elution of the minor compound $\mathbf{1}$ after 
that of the major compound 3 may be overlapped by the "tail" of the major compound 3. The mixture of compounds 1, 3, and $5(806.9 \mathrm{mg})$ was subjected to a second run of HSCCC using PL $+10 \% \mathrm{MeOH}(v / v)$ as the stationary phase and PU as the mobile phase, as described in Section 4.3, completely separating compounds 1 (24.1 mg), 3 (607.1 mg), and $5(21.3 \mathrm{mg})$ with purities of $97 \%, 99 \%$, and $96 \%$ by HPLC detection at $254 \mathrm{~nm}$ (Figure 3C,D). Moreover, the retention rate of the stationary phase increased to approximately $60 \%$, which contributed to a better separation resolution (Figure 3C).

Table 3. Modification of the solvent system $n$-hexane/EtOAc/MeOH/water $(2: 5: 2: 5, v / v)$ by adding $\mathrm{MeOH}$.

\begin{tabular}{|c|c|c|c|c|c|}
\hline \multirow{2}{*}{ Addition of $\mathrm{MeOH}$ to $\mathrm{PL}^{1}(v / v)$} & \multicolumn{4}{|c|}{$K^{2}$ Values of Compounds $1,3,5,7$} & \multirow{2}{*}{$\alpha_{K 1 / K 3}$} \\
\hline & 1 & 3 & 5 & 7 & \\
\hline PL alone & 1.16 & 0.90 & 2.59 & 7.89 & 1.29 \\
\hline $\mathrm{PL}+10 \% \mathrm{MeOH}^{3}$ & 0.85 & 0.58 & 1.42 & 21.15 & 1.47 \\
\hline $\mathrm{PL}+20 \% \mathrm{MeOH}^{4}$ & 0.6 & 0.37 & 1.22 & 6.20 & 1.62 \\
\hline $\mathrm{PL}+40 \% \mathrm{MeOH}^{5}$ & 0.23 & 0.10 & 0.32 & 0.67 & 2.30 \\
\hline
\end{tabular}

${ }^{1}$ Partitioned lower layer (PL) of the solvent system $n$-hexane/EtOAc/MeOH/water (2:5:2:5, $\left.v / v\right) .{ }^{2} \mathrm{~K}$ values were obtained by the new solvent system paired by the partitioned upper layer of $n$-hexane/EtOAc/MeOH/water $(2: 5: 2: 5, v / v)$ and the MeOH-modified PL. ${ }^{3}$ An extra $10 \%$ volume of MeOH was added to PL for polarity modification. ${ }^{4}$ An extra $20 \%$ volume of $\mathrm{MeOH}$ was added to PL for polarity modification. ${ }^{5}$ An extra $40 \%$ volume of $\mathrm{MeOH}$ was added to PL for polarity modification.

2.2.2. Pre-HPLC Separation of the Components in the $\mathrm{H}_{2} \mathrm{Cl}_{2}$ Fraction of $50 \% \mathrm{MeOH}$ Extract and the Components in the Partition Precipitate of MeOH Extract

With a simple component composition, the $\mathrm{H}_{2} \mathrm{Cl}_{2}$ fraction of the $50 \% \mathrm{MeOH}$ extract was used to separate compound 6 using pre-HPLC, as described in Section 4.4. From $100 \mathrm{mg}$ of the $\mathrm{H}_{2} \mathrm{Cl}_{2}$ fraction, $20.6 \mathrm{mg}$ of compound 3 and $16 \mathrm{mg}$ of compound 6 were separated (Figure $4 \mathrm{~A}, \mathrm{~B}$ ). The partition precipitate of the $\mathrm{MeOH}$ extract was used to separate compounds 2 and 4 due to relatively high content and simple component composition. Because the partition precipitate showed very low solubility in all the HSCCC solvent systems tested, it was separated by pre-HPLC, as described in Section 4.5, resulting in separation of $8.8 \mathrm{mg}$ of compound 2 and $6.9 \mathrm{mg}$ of compound 4 from $37.6 \mathrm{mg}$ of the partition precipitate (Figure 4C,D). Finally, compounds 1-7 were all separated.

The extraction, partition, and separation procedures are summarized in Figure 5 to present a clear experimental process.

\subsection{Structure Identification of the Separated Compounds 1-7}

The structures of the separated compounds from L. meyenii (1-7) are shown in Figure 6. Compounds 1-7 were identified via NMR (Tables S1 and S2), EI-MS and ESI-MS/MS analysis, and by comparison with previously published papers. The MS information of all the compounds is listed as follows.

Caffeic acid (1): yellow powder; EI-MS fragments $(\mathrm{m} / \mathrm{z})$ and intensity $(\%)$ : 180 (100.00\%), 163 (35.03\%), 136 (86.47\%), and 89 (65.64\%). The ${ }^{1} \mathrm{H}$ NMR (400 MHz, MeOD- $\left.d_{4}\right)$, as summarized in Table S1, was identical to [29]. The raw ${ }^{1} \mathrm{H}$ NMR spectrum is listed in Figure S3.

Hesperidin (2): white powder; ESI-MS/MS $m / z$ : negative ion, primary mass spectrum (MS) ion $[\mathrm{M}-\mathrm{H}]^{-}$609.1; major fragment ions of the secondary mass spectrum (MS/MS) from $[\mathrm{M}-\mathrm{H}]^{-}, 609.1,343.3,325.3,301.1$, and 286.0 [30]. Positive ion, primary MS ion $[\mathrm{M}+\mathrm{H}]^{+}$ 611.5; major fragment ions of MS/MS from [M-H] $]^{+} 611.5$ and 303.2 [31]. The ${ }^{1} \mathrm{H}$ NMR $\left(600 \mathrm{MHz}, \mathrm{DMSO}-d_{6}\right)$, as summarized in Table S2, was identical to $[32,33]$. The raw ${ }^{1} \mathrm{H}$ NMR, ${ }^{1} \mathrm{H}-{ }^{1} \mathrm{H}$ COSY NMR spectra, and ESI-MS/MS data are listed in Figure S4. 

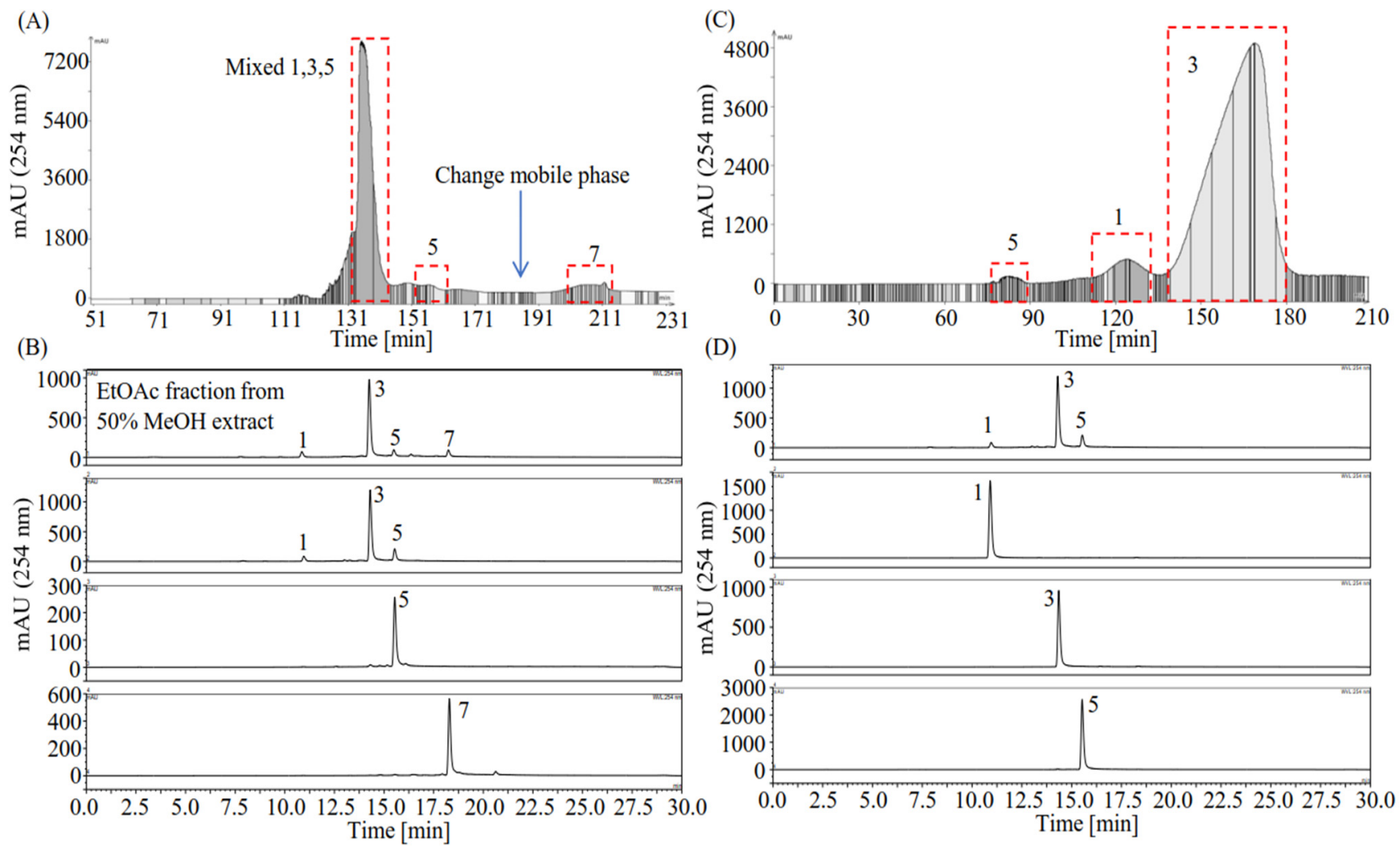

Figure 3. HSCCC and HPLC chromatograms of the EtOAc fraction of the 50\% MeOH extract of Lepechinia meyenii (Walp.) Epling (L. meyenii). (A) Polarity-gradient HSCCC separation of the EtOAc fraction of the 50\% MeOH extract of L. meyenii using the upper layer (PU) of $n$-hexane/EtOAc/MeOH/water $(2: 5: 2: 5, v / v)$ as the stationary phase, and $10 \%$ volume $\mathrm{MeOH}$-modified lower layer ( $\mathrm{PL}+10 \% \mathrm{MeOH}, v / v)$ of the solvent system as the first mobile phase to elute compounds 1, 3, and 5, and 40\% volume $\mathrm{MeOH}$-modified lower layer ( $\mathrm{PL}+40 \% \mathrm{MeOH}, v / v)$ of the solvent system as the second mobile phase for isolating compound 7. The elution rate was $3 \mathrm{~mL} / \mathrm{min}$. (B) HPLC chromatograms of the EtOAc fraction and the isolated compounds by polarity-gradient HSCCC. (C) HSCCC separation of compounds 1, 3, and 5 from the polarity-gradient HSCCC subfraction, using $\mathrm{PL}+10 \% \mathrm{MeOH}(v / v)$ as the stationary phase, and PU as the mobile phase with an elution rate of $3 \mathrm{~mL} / \mathrm{min}$. (D) HPLC chromatograms of the polarity-gradient HSCCC subfraction and the separated compounds 1, 3, and 5 by the second time HSCCC. Notably, the compounds to be separated were later identified as caffeic acid (1), rosmarinic acid (3), methyl rosmarinate (5), and butyl rosmarinate (7).

Rosmarinic acid (3): yellowish powder; EI-MS fragments $(\mathrm{m} / \mathrm{z})$ and intensity $(\%): 360$ (0.39\%), 212 (11.94\%), 198 (17.14\%), 194 (15.64\%), 180 (37.96\%), 179 (17.17\%), 163 (19.33\%), 136 (100\%), 123 (98.35\%), 107 (14.15\%), 89 (27.00\%), 77 (26.93\%), 51 (10.64). The ${ }^{1} \mathrm{H}$ NMR $\left(600 \mathrm{MHz}, \mathrm{MeOH}-d_{4}\right)$, as summarized in Table S1, was identical to [34]. The raw ${ }^{1} \mathrm{H}$ NMR and ${ }^{1} \mathrm{H}-{ }^{1} \mathrm{H}$ COSY NMR spectra are listed in Figure S5.

Diosmin (4): white powder; ESI-MS/MS $m / z$ : negative ion, primary mass spectrum (MS) ion $[\mathrm{M}-\mathrm{H}]^{-}$607.2; major fragment ions of the secondary mass spectrum (MS/MS) from $[\mathrm{M}-\mathrm{H}]^{-}, 607.2,299.2,284.2,255.0,227.0$, and 151.0. Positive ion, primary MS ion $[\mathrm{M}+\mathrm{H}]^{+}$301.2; major fragment ions of MS/MS from $[\mathrm{M}-\mathrm{H}]^{+}$609.2, 463.2, 301.2, 286.2, 258.2, 229.2, and 153.0 [35]. The ${ }^{1} \mathrm{H}$ NMR (600 MHz, DMSO- $\left.d_{6}\right)$, as summarized in Table S2, was identical to [33]. The raw ${ }^{1} \mathrm{H}$ NMR, ${ }^{1} \mathrm{H}-{ }^{1} \mathrm{H}$ COSY NMR spectra, and ESI-MS/MS data are listed in Figure S6.

Methyl rosmarinate (5): yellowish powder; EI-MS fragments $(\mathrm{m} / \mathrm{z})$ and intensity $(\%)$ : 374 (1.31\%), 279 (16.73\%), 167 (31.90\%), 149 (100.00\%), $127(10.66 \%), 113(20.98 \%), 112$ (15.08\%), 97 (18.87\%), 85 (20.68), 71 (38.05), 57 (51.97). The ${ }^{1} \mathrm{H}$ NMR (600 MHz, MeOH- $\left.d_{4}\right)$, as summarized in Table S1, was identical to [34,36]. The raw ${ }^{1} \mathrm{H}$ NMR spectrum is listed in Figure S7. 
Diosmetin (6): yellow powder; ESI-MS/MS $m / z$ : negative ion, primary mass spectrum (MS) ion $[\mathrm{M}-\mathrm{H}]^{-}$299.2; major fragment ions of the secondary mass spectrum (MS/MS) from $[\mathrm{M}-\mathrm{H}]^{-}, 299.2,284.2,256.0,227.0,151.0,133.0$, and 107.0. Positive ion, primary MS ion $[\mathrm{M}+\mathrm{H}]^{+}$301.2; major fragment ions of MS/MS from $[\mathrm{M}-\mathrm{H}]^{+}$301.2, 286.2, 258.2, 258.2, 229.2, 203.0, and 153.0 [35]. The ${ }^{1} \mathrm{H}$ NMR (600 MHz, DMSO- $\left.d_{6}\right)$ and the ${ }^{13} \mathrm{C}$ NMR (151 $\mathrm{MHz}, \mathrm{DMSO}-d_{6}$ ) as summarized in Table S2, were identical to [37]. The raw ${ }^{1} \mathrm{H}$ NMR, ${ }^{13} \mathrm{C}$ NMR spectra, and ESI-MS/MS data are listed in Figure S8.

$n$-Butyl rosmarinate (7): yellowish powder; EI-MS fragments $(\mathrm{m} / \mathrm{z})$ and intensity $(\%)$ : $416(0.14 \%), 302(14.80 \%), 254(100.00 \%), 236(59.02 \%), 180(62.07 \%), 163(21.30 \%), 153$ (43.69\%), 135 (25.10\%), 123 (96\%), 107 (30.75\%), 77 (39.12\%), 57 (21.53\%, 51 (10.08). The ${ }^{1} \mathrm{H}$ NMR ( $\left.400 \mathrm{MHz}, \mathrm{MeOH}-d_{4}\right)$, as summarized in Table S1, was identical to [34]. The raw ${ }^{1} \mathrm{H}$ NMR spectrum is listed in Figure S9.
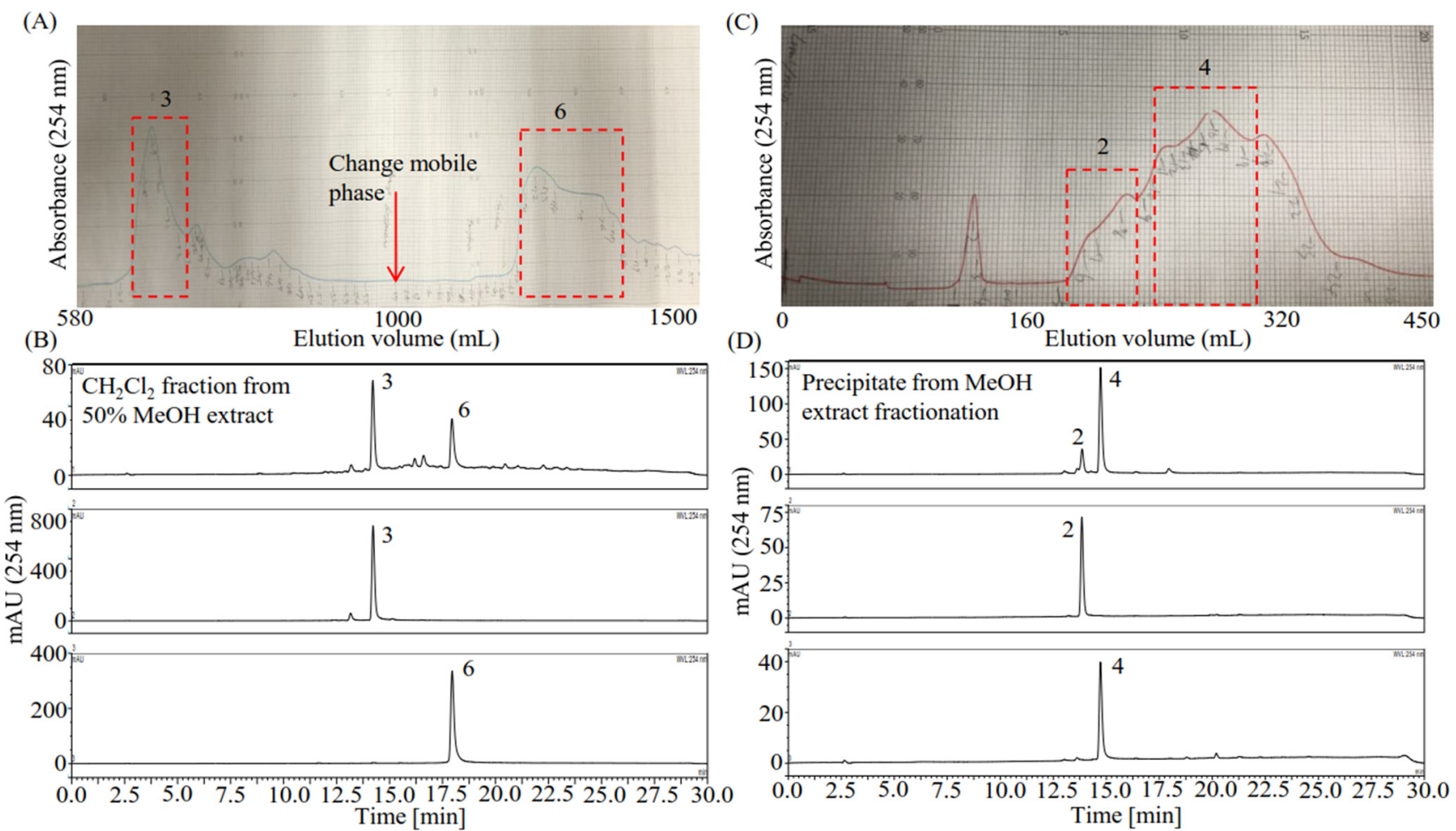

Figure 4. Pre-HPLC separation of the compounds from the $\mathrm{H}_{2} \mathrm{Cl}_{2}$ fraction of the $50 \% \mathrm{MeOH}$ extract and the partition precipitate from the MeOH extract fractionation process. (A) Pre-HPLC separation of components 3 and 6 from the $\mathrm{H}_{2} \mathrm{Cl}_{2}$ fraction of the $50 \% \mathrm{MeOH}$ extract. The sample $(100 \mathrm{mg})$ was first eluted by $50 \% \mathrm{MeOH}(0-1000 \mathrm{~mL} ; 4 \mathrm{~mL} / \mathrm{min})$ to obtain compound 3 (20.6 mg) and then eluted by $60 \% \mathrm{MeOH}(1000-1600 \mathrm{~mL} ; 4 \mathrm{~mL} / \mathrm{min})$ to obtain compound 6 (16 mg). (B) HPLC profiles of the $\mathrm{CH}_{2} \mathrm{Cl}_{2}$ fraction of $50 \% \mathrm{MeOH}$ extract and the separated compounds 3 and $\mathbf{6}$. (C) Pre-HPLC separation of components 2 and 4 from the partition precipitate. Compound $2(8.8 \mathrm{mg})$ and compound 4 (6.9 $\mathrm{mg})$ were separated from the mixture (37.6 mg) using 65\% MeOH $(0-450 \mathrm{~mL} ; 4 \mathrm{~mL} / \mathrm{min})$. (D) HPLC profiles of the partition precipitate of the MeOH extract and the separated compounds 2 and 4 . Notably, the compounds to be separated were later identified as hesperidin (2), rosmarinic acid (3), diosmin (4), and diosmetin (6).

\subsection{Synthesis, Purification, and Structural Identification of Rosmarinic Acid Ethyl and Propyl Esters}

To study the esterification effects of rosmarinic acid on its antioxidant and AR inhibitory activities, ethyl and propyl rosmarinates were further synthesized and separated, as described in Section 4.6. As monitored by HPLC, the esterification of rosmarinic acid with ethanol and propyl was almost completed within $72 \mathrm{~h}$ (Figures S1 and S2). A total of $73 \mathrm{mg}$ of ethyl rosmarinate and $80 \mathrm{mg}$ of propyl rosmarinate were obtained after the 
reaction solutions were centrifuged, filtered, and evaporated. However, the resulting compounds were not pure (Figures S1G and S2G) and were, therefore, purified by HSCCC, as described in Section 4.6, yielding high-purity ethyl rosmarinate (41.7 mg; Figure S1) and propyl rosmarinate ( $37.2 \mathrm{mg}$; Figure S2). The synthetic structures are listed in Figure 6 and confirmed as follows.

Ethyl rosmarinate (synthetic compound 1, S1): yellowish powder; EI-MS fragments $(m / z)$ and intensity (\%): 388 (8.04), 226 (82.82), 209 (100.00), 180 (97.46), 163 (93.90), 153 (37.63), 135 (59.98\%), 123 (64.24), 107 (25.03), 89 (36.62), 77 (52.79), 51 (15.14). The ${ }^{1} \mathrm{H}$ NMR (400 MHz, MeOH- $d_{4}$ ), as summarized in Table S1, was identical to [34]. The raw ${ }^{1} \mathrm{H}$ NMR spectrum is listed in Figure S10.

Propyl rosmarinate (synthetic compound 2, S2): yellowish powder; EI-MS fragments $(\mathrm{m} / \mathrm{z})$ and intensity (\%): 402 (3.27), 240 (100.00), 222 (95.39), 180 (97.63), 163 (97.65), 153 (67.18), 135 (38.98), 124 (82.11), 107 (31.60), 89 (16.86), 77 (51.68), 51 (13.74). The ${ }^{1} \mathrm{H}$ NMR $\left(400 \mathrm{MHz}, \mathrm{MeOH}-d_{4}\right)$, as summarized in Table S1, was identical to [34]. The raw ${ }^{1} \mathrm{H}$ NMR spectrum is listed in Figure S11.

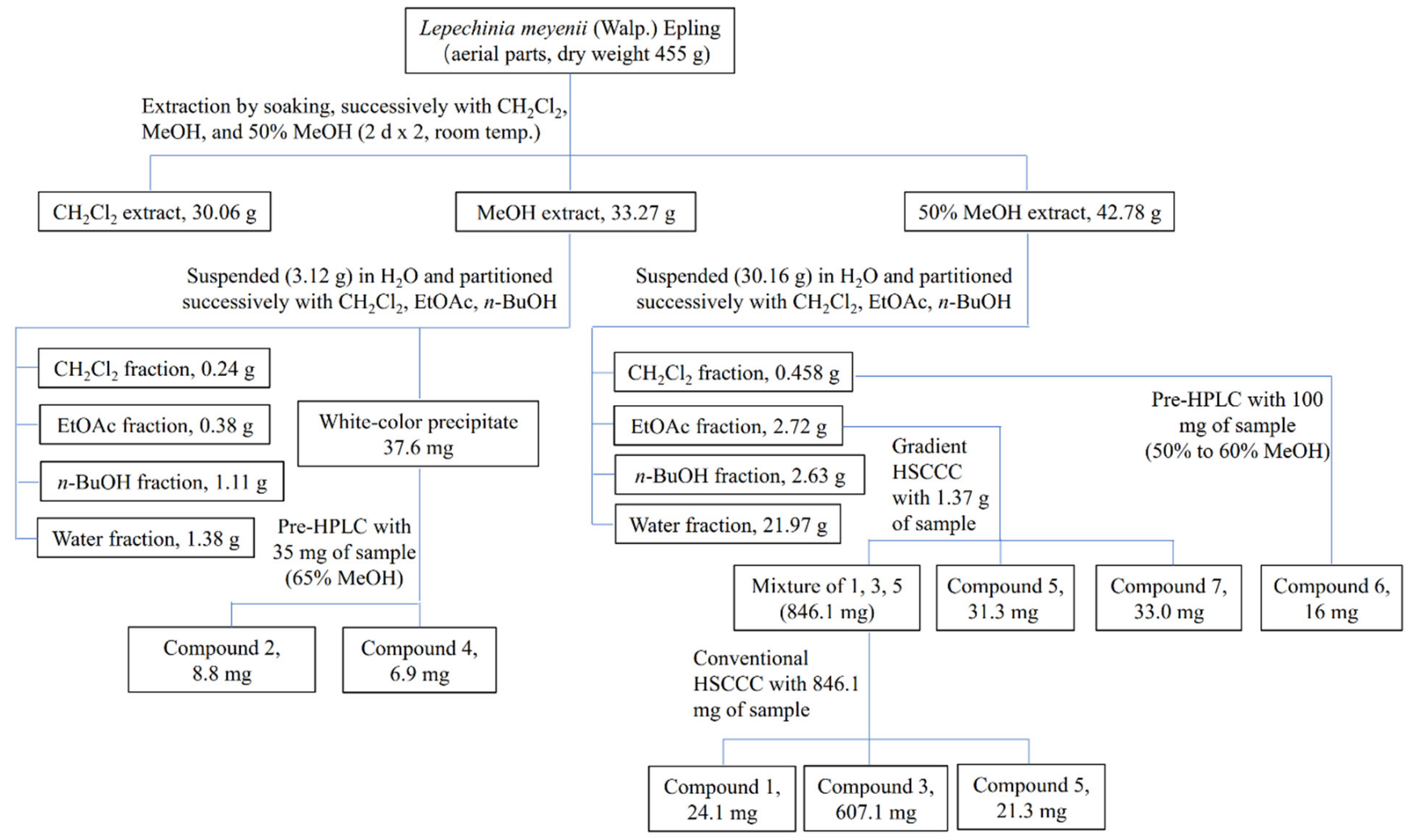

Figure 5. Extraction, fractionation, and separation processes of Lepechinia meyenii (Walp.) Epling (L. meyenii). Notably, compounds 1-7 were later identified as caffeic acid (1), hesperidin (2), rosmarinic acid (3), diosmin (4), methyl rosmarinate (5), diosmetin (6), and butyl rosmarinate (7).

\subsection{Antioxidant and AR Inhibitory Activities of the Separated and Synthesized Compounds}

Overall, rosmarinic acid and its methyl to $n$-butyl esters exhibited remarkable antioxidant activity (DPPH, $\mathrm{IC}_{50} 30.02-36.91 \mu \mathrm{M}$ ) and AR inhibitory activity ( $\mathrm{IC}_{50} 1.02-4.08$ $\mu \mathrm{M})$, which were higher than or similar to those of quercetin (DPPH, $\mathrm{IC}_{50} 33.19 \mu \mathrm{M}$; AR, $\left.\mathrm{IC}_{50} 16.16 \mu \mathrm{M}\right)$; whereas caffeic acid, hesperidine, diosmin, and diosmetin were less active against DPPH radicals (2.61-43.33\% inhibition at $50 \mu \mathrm{M})$ and AR (11.63-33.95\% inhibition at $50 \mu \mathrm{M})($ Table 4). In particular, the antioxidant and AR inhibitory activities of rosmarinic acid improved significantly after natural or synthetic esterification with $\mathrm{MeOH}, \mathrm{EtOH}$, 1-propanol, and $n$ - $\mathrm{BuOH}$. The antioxidant activities followed the order $n$-butyl rosmarinate 
$>$ ethyl rosmarinate $>$ propyl rosmarinate $>$ methyl rosmarinate $>$ rosmarinic acid, and their AR inhibitory activities followed the order ethyl rosmarinate $>$ methyl rosmarinate $>$ propyl rosmarinate $>n$-butyl rosmarinate $>$ rosmarinic acid. However, the DPPH scavenging activities between ethyl and $n$-butyl rosmarinates and the AR inhibitory activities among methyl, ethyl, propyl, and $n$-butyl rosmarinates were not significantly different $(p>0.05)$.

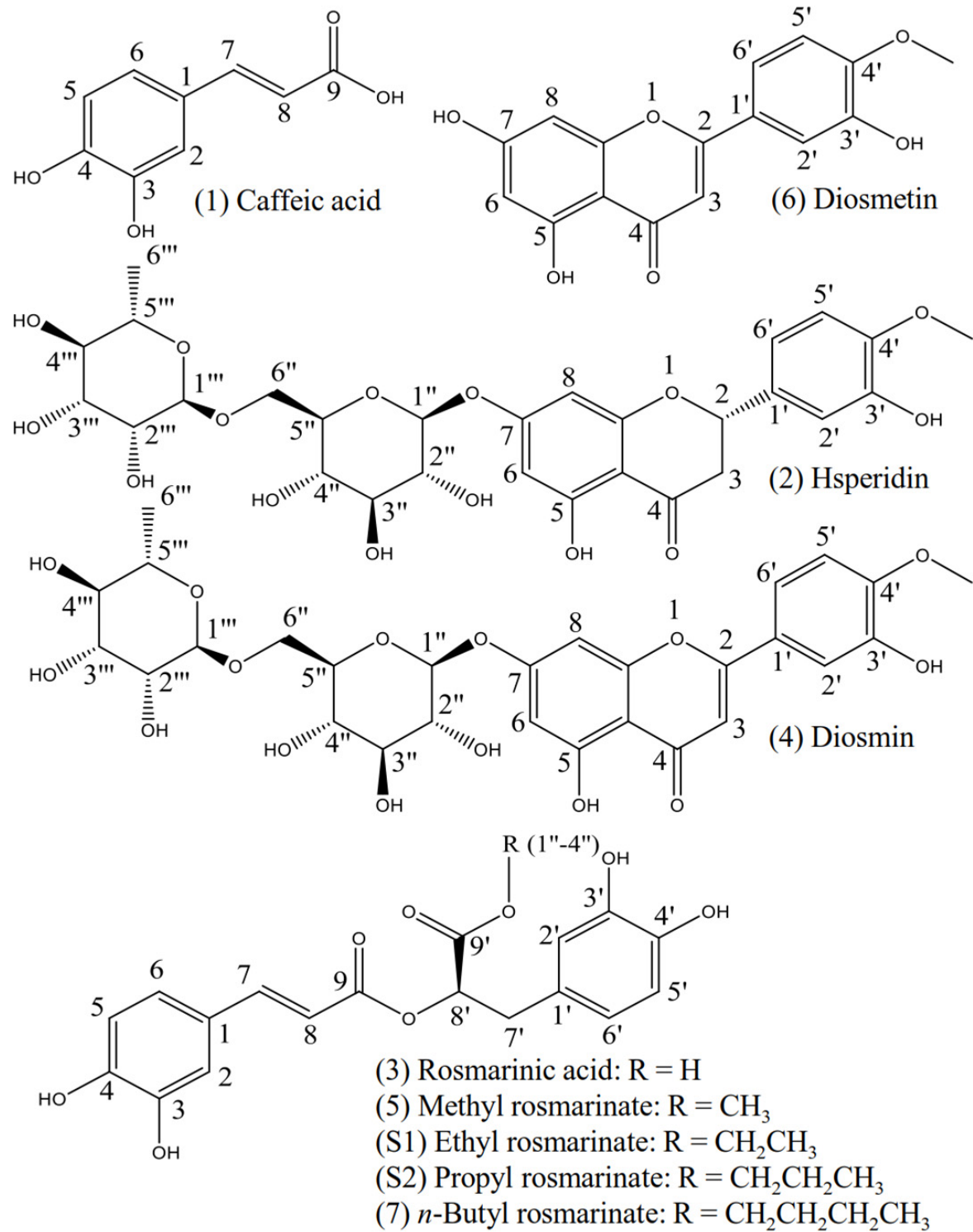

Figure 6. Structures of the separated compounds and synthetic compounds. Compounds 1-7 were separated from Lepechinia meyenii (Walp.) Epling, whereas S1 and S2 were synthetic components.

\subsection{Quantification of Rosmarinic Acid in the Extracts and Fractions of L. meyenii}

Possessing remarkable antioxidant and AR inhibitory activities, the major compound rosmarinic acid (3) in the extracts and fractions of L. meyenii was further quantified to better understand the proportion of rosmarinic acid and its contribution to the antioxidant and AR inhibitory activities. The HPLC quantification method was first validated by assessing the linearity, limit of detection, limit of quantification, precision, and accuracy (spike test), as described in Section 4.10. The standard curve of rosmarinic acid showed good linearity $\left(\mathrm{r}^{2}=1.00\right)$ within the concentrations determined $(0.39-400 \mu \mathrm{g} / \mathrm{mL} ;$ HPLC injection volume $10 \mu \mathrm{L}$ ), and the limit of detection and limit of quantification of rosmarinic 
acid were 0.15 and $0.39 \mu \mathrm{g} / \mathrm{mL}$, respectively (Table S3). The precision accessed by relative standard deviation was between $1.24 \%(100.00 \mu \mathrm{g} / \mathrm{mL})$ and $3.53 \%(12.50 \mu \mathrm{g} / \mathrm{mL})$ in the intra-day test, and between $1.47 \%(100.0 \mu \mathrm{g} / \mathrm{mL})$ and $4.85 \%(12.50 \mu \mathrm{g} / \mathrm{mL})$ in the inter-day test. The accuracy assessed using the spike recovery test was between $103.17 \%$ and $105.46 \%$ (Table S4). The quantification method was therefore validated by the obtained results and then applied to quantify rosmarinic acid.

Table 4. Antioxidant and aldose reductase (AR) inhibitory activity of the separated compounds from L. meyenii and synthetic ethyl and propyl rosmarinates.

\begin{tabular}{|c|c|c|c|c|c|c|}
\hline \multirow[b]{2}{*}{ Sample } & \multicolumn{3}{|c|}{ DPPH Scavenging Activity } & \multicolumn{3}{|c|}{ AR Inhibitory Activity (\%) } \\
\hline & $\begin{array}{c}\text { Concentration } \\
(\mu \mathrm{M})\end{array}$ & $\begin{array}{c}\text { Inhibition } \\
(\%)\end{array}$ & $\mathrm{IC}_{50}(\mu \mathrm{M})$ & $\begin{array}{c}\text { Concentration } \\
(\mu \mathrm{M})\end{array}$ & $\begin{array}{c}\text { Inhibition } \\
(\%)\end{array}$ & $\mathrm{IC}_{50}(\mu \mathrm{M})$ \\
\hline \multirow{3}{*}{ Caffeic acid (1) } & 50 & $43.33 \pm 0.69$ & & 50 & $20.34 \pm 0.62$ & \\
\hline & 25 & $20.21 \pm 0.58$ & - & 25 & $17.76 \pm 0.41$ & - \\
\hline & 12.5 & $8.60 \pm 0.87$ & & 12.5 & $12.31 \pm 2.09$ & \\
\hline \multirow{4}{*}{ Hesperidin (2) } & 50 & $3.37 \pm 1.32$ & & 50 & $11.63 \pm 0.41$ & \\
\hline & 25 & $2.57 \pm 0.77$ & - & 25 & $10.00 \pm 1.22$ & - \\
\hline & 12.5 & $1.20 \pm 1.18$ & & 12.5 & $1.78 \pm 0.33$ & \\
\hline & 50 & $67.04 \pm 0.64$ & & 12.5 & $75.97 \pm 1.03$ & \\
\hline \multirow{2}{*}{ Rosmarinic acid (3) } & 25 & $34.35 \pm 0.69$ & $36.91 \pm 0.35^{\mathrm{a}}$ & 6.25 & $62.93 \pm 2.10$ & $4.08 \pm 0.11^{b}$ \\
\hline & 12.5 & $19.05 \pm 1.33$ & & 3.125 & $42.65 \pm 1.63$ & \\
\hline \multirow{4}{*}{ Diosmin (4) } & 50 & $2.61 \pm 0.67$ & & 50 & $12.31 \pm 0.62$ & \\
\hline & 25 & $0.61 \pm 1.08$ & - & 25 & $11.22 \pm 0.82$ & - \\
\hline & 12.5 & $0.31 \pm 0.69$ & & 12.5 & $8.91 \pm 0.62$ & \\
\hline & 50 & $76.21 \pm 1.04$ & & 1.56 & $56.67 \pm 0.85$ & \\
\hline \multirow[t]{3}{*}{ Methyl rosmarinate (5) } & 25 & $37.59 \pm 0.60$ & $33.01 \pm 0.27^{b}$ & 0.78 & $40.88 \pm 3.47$ & $1.17 \pm 0.08^{\mathrm{c}}$ \\
\hline & 12.5 & $18.68 \pm 0.63$ & & 0.39 & $22.11 \pm 0.85$ & \\
\hline & 50 & $3.18 \pm 0.42$ & & 50 & $33.95 \pm 1.03$ & \\
\hline \multirow{3}{*}{ Diosmetin (6) } & 25 & $0.46 \pm 0.35$ & - & 25 & $21.97 \pm 1.25$ & - \\
\hline & 12.5 & $0.14 \pm 0.34$ & & 12.5 & $10.54 \pm 3.79$ & \\
\hline & 50 & $84.85 \pm 0.81$ & & 1.56 & $51.36 \pm 0.94$ & \\
\hline \multirow[t]{3}{*}{$n$-Butyl rosmarinate $(7)$} & 25 & $40.73 \pm 1.21$ & $30.02 \pm 0.10^{c}$ & 0.78 & $28.64 \pm 0.47$ & $1.54 \pm 0.04^{\mathrm{c}}$ \\
\hline & 12.5 & $19.98 \pm 0.29$ & & 0.39 & $13.13 \pm 0.47$ & \\
\hline & 50 & $83.09 \pm 0.21$ & & 1.56 & $60.48 \pm 2.05$ & \\
\hline \multirow[t]{3}{*}{ Ethyl rosmarinate (S1) } & 25 & $38.38 \pm 0.53$ & $30.54 \pm 0.13^{c}$ & 0.78 & $43.20 \pm 0.62$ & $1.02 \pm 0.07^{\mathrm{c}}$ \\
\hline & 12.5 & $22.02 \pm 0.35$ & & 0.39 & $27.41 \pm 2.66$ & \\
\hline & 50 & $77.82 \pm 0.46$ & & 1.56 & $53.67 \pm 0.41$ & \\
\hline \multirow[t]{3}{*}{ Propyl rosmarinate (S2) } & 25 & $37.15 \pm 0.29$ & $32.70 \pm 0.08^{b}$ & 0.78 & $37.89 \pm 1.25$ & $1.29 \pm 0.01^{\mathrm{c}}$ \\
\hline & 12.5 & $17.68 \pm 0.83$ & & 0.39 & $12.31 \pm 1.84$ & \\
\hline & 50 & $72.32 \pm 0.42$ & & 25 & $65.10 \pm 1.47$ & \\
\hline \multirow[t]{2}{*}{ Quercetin } & 25 & $40.39 \pm 0.82$ & $33.19 \pm 0.31^{b}$ & 12.5 & $44.97 \pm 1.65$ & $16.16 \pm 0.73^{a}$ \\
\hline & 12.5 & $22.31 \pm 0.92$ & & 6.25 & $31.50 \pm 1.70$ & \\
\hline
\end{tabular}

Note: Compounds 1-7 were separated from L. meyenii, but S1 and S2 were synthetic components. Quercetin was used as a positive control. Different superscript letters $\left({ }^{\mathrm{a}, \mathrm{b}, \mathrm{c}}\right)$ in each $\mathrm{IC}_{50}$ column indicate significant differences $(p<0.05)$, and "_" means $\mathrm{IC}_{50}$ values were not available within the concentrations tested.

As listed in Table 5, rosmarinic acid was rich in the $\mathrm{MeOH}$ extract $(33.84 \mathrm{mg} / \mathrm{g})$ and the $50 \% \mathrm{MeOH}$ extract $(135.41 \mathrm{mg} / \mathrm{g})$ of L. meyenii. In contrast, only a small amount of rosmarinic acid was present in the $\mathrm{H}_{2} \mathrm{Cl}_{2}$ extract $(1.24 \mathrm{mg} / \mathrm{g})$. Notably, after the partition of the $\mathrm{MeOH}$ extract, the rosmarinic acid content further increased to $804.07 \mathrm{mg} / \mathrm{g}$ and $373.71 \mathrm{mg} / \mathrm{g}$ in the EtOAc and $\mathrm{BuOH}$ fractions of the MeOH extract, respectively. Similarly, after partitioning the $50 \% \mathrm{MeOH}$ extract, the contents of rosmarinic acid also increased in the EtOAc fraction $(634.22 \mathrm{mg} / \mathrm{g})$ and $n$ - $\mathrm{BuOH}$ fraction $(426.22 \mathrm{mg} / \mathrm{g})$ of the $50 \% \mathrm{MeOH}$ extract. The contents of rosmarinic acid in the other fractions of the $\mathrm{MeOH}$ and $50 \% \mathrm{MeOH}$ extracts are listed in Table 5. Additionally, the content of rosmarinic acid in the dried raw material (aerial parts) of L. meyenii was calculated to be $37.22 \mathrm{mg} / \mathrm{g}$ (Table 5). 
Table 5. Contents of rosmarinic acid in extracts, fractions, and raw material of L. meyenii (mg/g).

\begin{tabular}{cc}
\hline Sample & Content (mg Component/g Sample) \\
\hline $\mathrm{H}_{2} \mathrm{Cl}_{2}$ extract & $1.24 \pm 1.00$ \\
$\mathrm{MeOH}$ extract & $333.84 \pm 2.74$ \\
$\mathrm{MeE} \mathrm{CH} \mathrm{Cl}_{2}$ fr. & $16.97 \pm 1.25$ \\
$\mathrm{MeE} \mathrm{EtOAc} \mathrm{fr.}$ & $804.07 \pm 4.07$ \\
$\mathrm{MeE} \mathrm{BuOH} \mathrm{fr.}$ & $373.71 \pm 2.78$ \\
$\mathrm{MeE} \mathrm{water} \mathrm{fr.}$ & $140.14 \pm 0.11$ \\
$50 \% \mathrm{MeOH}$ extract & $135.41 \pm 0.54$ \\
$50 \% \mathrm{MeE} \mathrm{CH}_{2} \mathrm{Cl}_{2}$ fr. & $118.54 \pm 0.38$ \\
$50 \% \mathrm{MeE} \mathrm{EtOAc} \mathrm{fr.}$ & $634.22 \pm 3.37$ \\
$50 \% \mathrm{MeE} \mathrm{BuOH} \mathrm{fr.}$ & $426.22 \pm 2.56$ \\
$50 \% \mathrm{MeE} \mathrm{water} \mathrm{fr.}$ & $20.49 \pm 0.55$ \\
Dried raw material & 37.22 \\
\hline
\end{tabular}

Note: "MeE", "50\% MeE", and "fr." are the abbreviations of MeOH extract, 50\% MeOH extract, and fraction, respectively. Values are presented as mean \pm standard deviation. The contents of rosmarinic acid in the extracts and fractions of L. meyenii were quantified by HPLC, whereas the content of rosmarinic acid in the dried raw material (aerial parts) of L. meyenii was calculated.

\section{Discussion}

We previously reported that L. meyenii showed strong antioxidant and AR inhibitory activities [15]. In this study, we proved that rosmarinic acid (3), methyl rosmarinate (5), and butyl rosmarinate (7) are the main active compounds in L. meyenii with remarkable antioxidant and AR inhibitory activities. In particular, rosmarinic acid is the key contributor to the antioxidant and AR inhibitory activities of L. meyenii, which is rich in the $\mathrm{MeOH}$ extract $(333.84 \mathrm{mg} / \mathrm{g})$ and $50 \% \mathrm{MeOH}$ extract $(135.41 \mathrm{mg} / \mathrm{g})$ of L. meyenii, and is especially abundant in the EtOAc and $n-\mathrm{BuOH}$ fractions $(373.71-804.07 \mathrm{mg} / \mathrm{g}$ ) of the $\mathrm{MeOH}$ and $50 \%$ $\mathrm{MeOH}$ extracts.

Herbal medicine plays an important role in the treatment of diabetes. Yet the underlying bioactive compounds of some plants are still unclear. In this study, we provided the HPLC profiles of all the extracts (Figure 1) and fractions (Figure 2) of L. meyenii, identified seven main compounds in its active extracts and fractions (Figure 6), and quantified the contents of the principal compound, rosmarinic acid (3), in all the extracts and fractions of L. meyenii (Table 5). These findings provide scientific evidence confirming its phytochemical composition and promotes its application. Notably, rosmarinic acid (3) is rich in the $\mathrm{MeOH}$ and $50 \% \mathrm{MeOH}$ extracts $(135.41-333.84 \mathrm{mg} / \mathrm{mL})$, and the contents of rosmarinic acid in the EtOAc and $\mathrm{BuOH}$ fractions of the $\mathrm{MeOH}$ and $50 \% \mathrm{MeOH}$ extracts remarkably increased (373.71-804.07 mg/g) after the simple solvent-solvent fractionation process (Table 5). Moreover, the content of rosmarinic acid in the dried raw material of L. meyenii was calculated to be $37.22 \mathrm{mg} / \mathrm{g}$ (Table 5), which is comparable to many popular rosmarinic acid-rich plants including Salvia officinalis (8.5-14.1 mg/g), Rosmarinus officinalis $(10-11 \mathrm{mg} / \mathrm{g})$, Mentha spicata L. (7.1-14.3 mg/g), and Melissa officinalis L. (27.4 mg/g) [38]. This indicates that L. meyenii is a promising source for the industrial production of rosmarinic acid. Rosmarinic acid (3) was identified as the key contributor to the antioxidant and AR inhibitory activities of L. meyenii, as the rosmarinic acid content $(\mathrm{mg} / \mathrm{g})$ showed a strong positive and significant correlation with the activities against DPPH radicals $(r=0.945, p<0.001)$ and AR $(r=0.923, p<0.001)$ in the extracts/fraction of L. meyenii (Figure 7). In addition to rosmarinic acid (3), six more compounds were separated and identified from L. meyenii, including caffeic acid (1), hesperidin (2), diosmin (4), methyl rosmarinate (5), diosmetin (6), and butyl rosmarinate (7), among which caffeic acid, rosmarinic acid, and methyl rosmarinate have previously been reported in L. meyenii $[16,39]$. In contrast, hesperidin, diosmin, diosmetin, and butyl rosmarinate were identified in L. meyenii for the first time in this study. Among these identified compounds, rosmarinic acid derivatives $(3,5,7)$ showed higher antioxidant and AR inhibitory activities than the other compounds $(\mathbf{1}, \mathbf{2}, \mathbf{4}, \mathbf{6})$ (Table 4). Nevertheless, hesperidin (2) [40,41], diosmin (4) [42,43], and diosmetin (6) [44] also show anti-diabetic properties with diabetic neuroprotective and antihyperglycemic effects or via 
up-regulating the IRS/PI3K/AKT signaling pathway. Our study adds scientific evidence to the existing literature about this traditional anti-diabetic herbal medicine, L. meyenii [8], its antioxidant properties, AR inhibitory activity, phytochemical composition, and rosmarinic acid content.

(A)

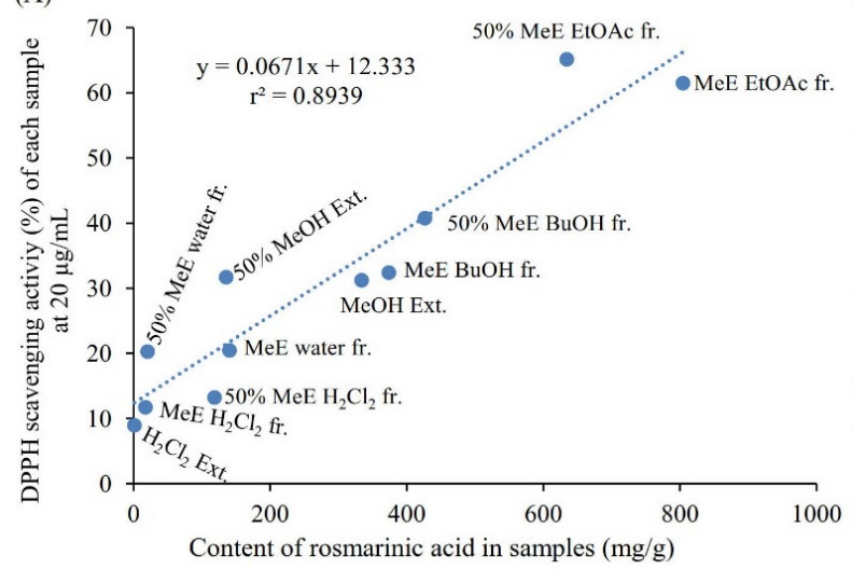

(B)

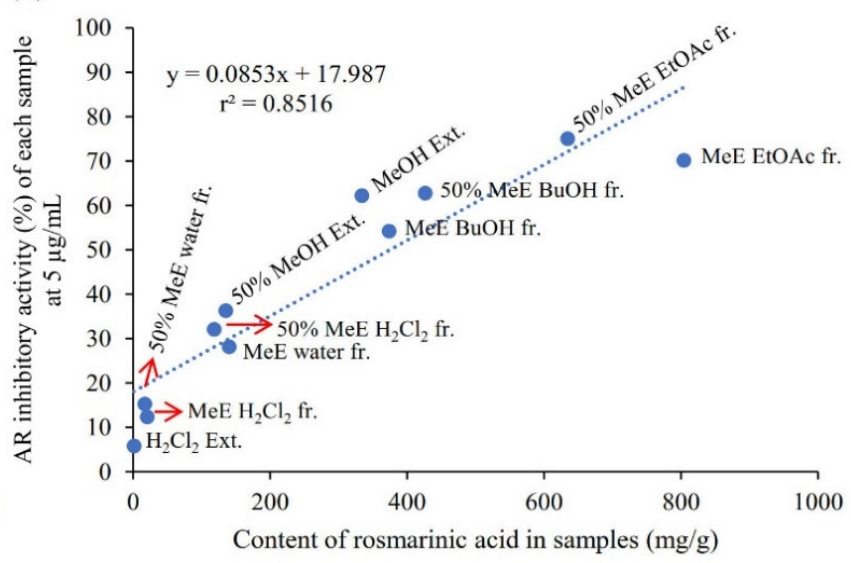

Figure 7. Correlations of the content of rosmarinic acid in the extracts/fractions of Lepechinia meyenii (Walp.) Epling and their activities against DPPH radicals (sample concentration $20 \mu \mathrm{g} / \mathrm{mL})(r=0.945, p<0.001)(\mathbf{A})$ and aldose reductase (AR) (sample concentration $5 \mu \mathrm{g} / \mathrm{mL})(r=0.923, p<0.001)(B)$. "MeE", "50\% MeE", "Ext." and "fr." are the abbreviations of "MeOH extract", " $50 \% \mathrm{MeOH}$ extract", "extract" and "fraction", respectively.

Moreover, the present study demonstrated that esterification of rosmarinic acid with short-chain primary alcohols $\left(C_{1}-C_{4}\right)$ significantly enhanced its antioxidant and AR inhibitory activities (Table 4). A previous study reported that esterification of rosmarinic acid using short to medium chain primary alcohols $\left(\mathrm{C}_{4}, \mathrm{C}_{10}\right.$, and $\left.\mathrm{C}_{16}\right)$ can increase cell uptake and boost antioxidant activity without significant cytotoxicity [45], whereas a more recent study showed that only short-chain $(\leq \mathrm{C} 4)$ esterification of rosmarinic acid can increase its bioavailability, and esterification with longer alkyl chains leads to severe cytotoxicity [46]. However, no studies have been carried out to compare the antioxidant activity among rosmarinic acid and its short-chain esters $(\leq \mathrm{C} 4)$. Considering that rosmarinic acid, methyl rosmarinate, and butyl rosmarinate were previously separated from L. meyenii (Figure 3), we then synthesized ethyl and propyl rosmarinates (Figures S1 and S2). Furthermore, DPPH scavenging assay revealed that the antioxidant potential of rosmarinic acid (DPPH IC $_{50} 36.91 \mu \mathrm{M}$ ) was significantly increased after being esterified using short-chain primary alcohols $\left(\mathrm{C}_{1}-\mathrm{C}_{4}\right.$, DPPH IC $\mathrm{I}_{50}$ 30.02-33.01 $\mu \mathrm{M}$ ) (Table 4), among which ethyl rosmarinate (DPPH IC $5030.54 \mu \mathrm{M}$ ) and butyl rosmarinate (DPPH IC $5030.02 \mu \mathrm{M}$ ) exhibited the highest antioxidant potential (Table 4). Moreover, the AR inhibitory activity of rosmarinic acid ( $\mathrm{IC}_{50} 4.08 \mu \mathrm{M}$ ) was also significantly increased after being esterified to methyl-butyl rosmarinates $\left(\mathrm{IC}_{50} 1.02-1.54 \mu \mathrm{M}\right)$ (Table 4). Notably, ethyl rosmarinate $\left(\mathrm{IC}_{50} 1.02 \mu \mathrm{M}\right)$ was four times more potent than rosmarinic acid $\left(\mathrm{IC}_{50} 4.08 \mu \mathrm{M}\right)$ and approximately 16 times more potent than the positive control quercetin $\left(\mathrm{IC}_{50} 16.16 \mu \mathrm{M}\right)$ [23]. Apparently, with ethyl rosmarinate as the node, increasing the chain length of the primary alcohols tends to reduce the AR inhibitory activity of rosmarinic acid esters despite there being no significant differences among methyl-butyl rosmarinates regarding AR inhibition (Table 4). In addition to esterification of rosmarinic acid by short-chain primary alcohols $(\leq \mathrm{C} 4)$, amination of rosmarinic acid using phenylmethanamine, 4-(aminomethyl)phenol, and 1-phenylethan-1-amine was also reported to improve its AR inhibitory activity [47], indicating that derivatization of the hydroxy group connected to $9^{\prime}-\mathrm{C}$ in rosmarinic acid is a promising strategy to improve its bioactivity regarding antioxidation, AR inhibition, and even protein kinase B (Akt) inhibition [48]. 
In addition, the HSCCC separation method established in this study is a promising method for preparative separation of rosmarinic acid from L. meyenii and other natural products. Chen et al. previously separated $1.9 \mathrm{mg}$ of rosmarinic acid from Salvia miltiorrhiza Bunge ( $80 \mathrm{mg}$ ) by HSCCC using solvent system $n$-hexane/EtOAc/MeOH/water (1.5:5:5:1.5, $v / v)$ [49]. Xie et al. selected $n$-hexane/EtOAc/MeOH/water $(1: 4: 1: 4, v / v)$ as the solvent system and separated $11 \mathrm{mg}$ of rosmarinic acid from $100 \mathrm{mg}$ of EtOAc extract of Glechoma hederacea L. by HSCCC [50]. Kwon et al. succeeded in separation of $20.4 \mathrm{mg}$ of rosmarinic acid from $200 \mathrm{mg}$ of EtOAc fraction of Perilla frutescens using step-wise HSCCC [51]. More recently, Zhu et al. separated $8 \mathrm{mg}$ of rosmarinic acid from $160 \mathrm{mg}$ of L. meyenii by HSCCC and pre-HPLC using $n$-hexane/EtOAc/MeOH/water (3:5:3:5 $+1.5 \%$ acetic acid, $v / v$ ) as the HSCCC solvent system [52]. Using PL $+10 \% \mathrm{MeOH}(v / v)$ as the stationary phase and PU as the mobile phase, $607.1 \mathrm{mg}$ of high-purity rosmarinic acid (99\%) was separated from $806.9 \mathrm{mg}$ of L. meyenii subfraction (Figure 3) in this study, where PL and PU are the abbreviations of the partitioned lower layer and partitioned upper layer of the solvent system $n$-hexane/EtOAc/MeOH/water (2:5:2:5, v/v), respectively.

\section{Materials and Methods}

\subsection{Reagents and Plant}

2,2-Diphenyl-1-picrylhydrazyl (DPPH), quercetin, DL-glyceraldehyde (dimer), $\beta$ nicotinamide adenine dinucleotide 2 '-phosphate reduced tetrasodium salt hydrate (NADPH), glacial acetic acid, sodium phosphate dibasic dodecahydrate, trifluoroacetic acid, potassium phosphate monobasic, ethanol (99.8\%), 1-propanol (99.7\%), rosmarinic acid (97\%), and sodium phosphate dibasic dehydrate were procured from Sigma-Aldrich Chemical Co. (St. Louis, MI, USA). An Amberlite ${ }^{\circledR} \mathrm{IR}-120$ ( $\mathrm{H}^{+}$form) ion exchanger and ammonium sulfate were purchased from Merck KGaA Co. (Darmstadt, Germany). A 3A molecular sieve was purchased from Consolidated Chemical \& Solvents LLC. (Quakertown, PA, USA). The other organic solvents were purchased from J. T. Baker Co. (Phillipsburg, NJ, USA), including HPLC grade for HPLC and preparative HPLC (Pre-HPLC) assays and analytical grade for extraction, fractionation, and HSCCC separations. The ultrapure water used in this study was produced using a Milli-Q water purification system (Millipore Co., Bedford, MA, USA).

The aerial parts of L. meyenii were collected from Lima, and the specimen was authenticated by Paul H. Gonzales Arce (P.H.G.A.). The dried material was placed at the Center for Efficacy Assessment and Development of Functional Foods and Drugs, Hallym University.

\subsection{Extraction and Partition of L. meyenii}

The dried aerial parts of L. meyenii ( $455 \mathrm{~g}$ ) were successively extracted by $5 \mathrm{~L}$ of dichloromethane $\left(\mathrm{CH}_{2} \mathrm{Cl}_{2}\right)(2 \times 2 \mathrm{~d}), \mathrm{MeOH}(2 \times 2 \mathrm{~d})$, and $50 \% \mathrm{MeOH}$ aqueous solution $(2 \times 2 \mathrm{~d})$ at room temperature (approximately $22-28{ }^{\circ} \mathrm{C}$ ). The two extraction solutions of each extraction solvent were combined, filtered, and evaporated to dryness by rotary evaporation $\left(37^{\circ} \mathrm{C}\right)$, yielding $30.06 \mathrm{~g}$ of $\mathrm{CH}_{2} \mathrm{Cl}_{2}$ extract, $33.27 \mathrm{~g}$ of $\mathrm{MeOH}$ extract, and $42.78 \mathrm{~g}$ of $50 \% \mathrm{MeOH}$ extract.

Then, the MeOH extract $(3.12 \mathrm{~g})$ was suspended in water $(100 \mathrm{~mL})$ assisted by sonication and partitioned twice by an equal volume of $\mathrm{CH}_{2} \mathrm{Cl}_{2}$, EtOAc, and $n-\mathrm{BuOH}$ to yield sub-fractions of $\mathrm{CH}_{2} \mathrm{Cl}_{2}(0.24 \mathrm{~g})$, EtOAc $(0.38 \mathrm{~g}), n-\mathrm{BuOH}(1.11 \mathrm{~g})$, and water (1.38 g). Notably, a white-color precipitate was produced during the partition process, which was separately collected and evaporated, yielding $37.6 \mathrm{mg}$ of powder.

Similarly, the $50 \% \mathrm{MeOH}$ extract was also subjected to partition procedure by suspending $30.16 \mathrm{~g}$ of extract in $1 \mathrm{~L}$ of water and partitioning the solution using $\mathrm{CH}_{2} \mathrm{Cl}_{2}(2 \times 1 \mathrm{~L})$, EtOAc $(2 \times 1 \mathrm{~L})$, and $n-\mathrm{BuOH}(2 \times 1 \mathrm{~L})$ to yield sub-fractions of $\mathrm{CH}_{2} \mathrm{Cl}_{2}(0.46 \mathrm{~g})$, EtOAc $(2.73 \mathrm{~g}), n-\mathrm{BuOH}(2.63 \mathrm{~g})$, and water $(21.97 \mathrm{~g})$. 


\subsection{Separation of Components from the EtOAc Fraction of 50\% MeOH Extract by HSCCC} 4.3.1. Screening and Modification of HSCCC Solvent System

As described previously, screening of HSCCC solvent systems, composed of $n$-hexane, EtOAc, $\mathrm{MeOH}$, and water, was carried out [53]. Briefly, each solvent system was prepared, thoroughly mixed, and divided into upper and lower phases after settling. Then a proper amount of sample (the EtOAc fraction of the $50 \% \mathrm{MeOH}$ extract; $0.1-0.5 \mathrm{mg}$ ) was weighed in a $1.5 \mathrm{~mL}$ tube and dissolved by $1 \mathrm{~mL}$ of a solvent composed of $500 \mu \mathrm{L}$ of upper phase and $500 \mu \mathrm{L}$ of lower phase. The sample solution was thoroughly mixed by a vortex to equilibrate the contents. After settling, equal volumes of the upper and lower layers (each $200 \mu \mathrm{L}$ ) of the sample solution were transferred respectively to new $1.5 \mathrm{~mL}$ tubes and evaporated by nitrogen gas, which were then re-dissolved using $200 \mu \mathrm{L}$ of $\mathrm{MeOH}$ and subjected to HPLC detection (injection volume $10 \mu \mathrm{L}$ ). The $K$ value is calculated as $A_{\text {upper }} / A_{\text {lower, }}$, where $A_{\text {upper }}$ and $A_{\text {lower }}$ are the HPLC peak areas of a compound in the upper and lower layers, respectively. However, the solvent systems tested could not provide satisfactory $K$ values and $\alpha$ values, which were further modified as follows.

Adding 0.1\% volume of acetic acid to $n$-hexane/EtOAc/MeOH/water (2:5:2:5, v/v) was first carried out to modify, but failed to improve, the solvent system, which was further modified by adding $\mathrm{MeOH}$. Briefly, the solvent system $n$-hexane/EtOAc/MeOH/water $(2: 5: 2: 5, v / v)$ was prepared and partitioned into the upper layer (PU) and lower layer (PL). Next, a $10-40 \%$ volume of $\mathrm{MeOH}$ was added to PL to obtain MeOH-modified PLs. As mentioned above, the MeOH-modified PLs were individually paired with PU to form new solvent systems for determining $K$ values and $\alpha$ values. Finally, PL $+10 \% \mathrm{MeOH}(v / v)$ and $\mathrm{PL}+40 \% \mathrm{MeOH}(v / v)$ were selected to pair new solvent systems with PU to separate the compounds from the EtOAc fraction of the $50 \% \mathrm{MeOH}$ extract in polarity-gradient and polarity-constant manners.

\subsubsection{Preparation of Solvent System and HSCCC Separation}

The solvent system $n$-hexane/EtOAc/MeOH/water (2:5:2:5, $v / v)$ was prepared and separated into PL and PU using a funnel. Then PL $+10 \% \mathrm{MeOH}(v / v)$ and PL $+40 \% \mathrm{MeOH}$ $(v / v)$ were prepared by adding extra $\mathrm{MeOH}$ to PL. Solvents PU, $\mathrm{PL}+10 \% \mathrm{MeOH}(v / v)$, and $\mathrm{PL}+40 \% \mathrm{MeOH}(v / v)$ were degassed by sonication for $30 \mathrm{~min}$ before use. A TBE 300C HSCCC (Tauto Biotech. Co., Ltd., Shanghai, China) with three preparative coils (diameter $2.6 \mathrm{~mm}$; total volume $300 \mathrm{~mL}$ ) was used for separation. An Isolera FLASH purification system (Biotage, Uppsala, Sweden) was fitted to the HSCCC machine as a pump, UV monitor, and fraction collector.

HSCCC separation of the sample was first performed in a polarity-gradient elution manner. Briefly, PU was used as the stationary phase to completely fill the HSCCC coil, and the rotational speed was adjusted to $900 \mathrm{rpm}$. Subsequently, solvent $\mathrm{PL}+10 \% \mathrm{MeOH}(v / v)$ was introduced as the first mobile phase at $3 \mathrm{~mL} / \mathrm{min}$ until a hydrodynamic equilibrium was achieved. Then, the sample solution $(15 \mathrm{~mL}$ ) was loaded to the sample loop (maximum $20 \mathrm{~mL}$ ), which was prepared by dissolving $1.37 \mathrm{~g}$ of the EtOAc fraction of the $50 \% \mathrm{MeOH}$ extract in $15 \mathrm{~mL}$ of biphasic solvents composed of $7 \mathrm{~mL}$ of PU and $8 \mathrm{~mL}$ of PL $+10 \% \mathrm{MeOH}$ $(v / v)$. Next, the sample was eluted $(3 \mathrm{~mL} / \mathrm{min})$ by $\mathrm{PL}+10 \% \mathrm{MeOH}(v / v)$ (the first mobile phase; $0-360 \mathrm{~mL}$ ) for compounds 1,3 , and 5 , and eluted ( $3 \mathrm{~mL} / \mathrm{min}$ ) by $\mathrm{PL}+40 \% \mathrm{MeOH}$ $(v / v)$ (the second mobile phase; $360-510 \mathrm{~mL}$ ) for compound 7 . The eluate was monitored at $254 \mathrm{~nm}$. After completing the separation, the solvent was pumped out in air and collected by a graduated cylinder to calculate the retention ratio of the stationary phase, which was calculated as $V \mathrm{~s} / V \mathrm{c}$, where $V \mathrm{~s}$ is the stationary phase volume retained in the column coil, and $V \mathrm{c}$ is the HSCCC column coil volume $(300 \mathrm{~mL})$.

Components 1, 3, and a small amount of 5 were concentrated as a mixture by the polarity-gradient elution HSCCC, which were further separated by polarity-constant elution HSCCC using PL $+10 \% \mathrm{MeOH}(v / v)$ as the stationary phase and PU as the mobile phase. Briefly, the HSCCC coil was filled with solvent PL $+10 \% \mathrm{MeOH}(v / v)$, and the rotational speed was adjusted to $900 \mathrm{rpm}$. Next, PU was pumped in at $3 \mathrm{~mL} / \mathrm{min}$ until 
a hydrodynamic equilibrium was achieved. Subsequently, $0.81 \mathrm{~g}$ of the mixture fraction, mainly composed of $\mathbf{1}, \mathbf{3}$, and $\mathbf{5}$, was dissolved in $15 \mathrm{~mL}$ of biphasic solvents consisting of $7 \mathrm{~mL}$ of PU and $8 \mathrm{~mL}$ of PL $+10 \% \mathrm{MeOH}(v / v)$ and loaded for HSCCC separation. The mobile phase elution speed was $3 \mathrm{~mL} / \mathrm{min}$, and the eluate was monitored at $254 \mathrm{~nm}$.

\subsection{Separation of the Components in the $\mathrm{H}_{2} \mathrm{Cl}_{2}$ Fraction of $50 \% \mathrm{MeOH}$ Extract by Pre-HPLC}

The separation was performed on a pre-column $(\Phi 20 \times 500 \mathrm{~mm}$; JAIGEL-GS310 $)$ equipped with LC-908 preparative HPLC (JAI, Japan). Approximately $100 \mathrm{mg}$ of the $\mathrm{H}_{2} \mathrm{Cl}_{2}$ fraction of the $50 \% \mathrm{MeOH}$ extract was dissolved in $1.5 \mathrm{~mL}$ of $\mathrm{MeOH}$, filtered $(0.22 \mu \mathrm{m}$; Millipore Millex-GP, Bedford, MA, USA), and loaded to a sample loop (maximum volume $2 \mathrm{~mL}$ ) for purification, which was successively eluted by $50 \% \mathrm{MeOH}(0-1000 \mathrm{~mL} ; 4 \mathrm{~mL} / \mathrm{min})$ and $60 \% \mathrm{MeOH}(1000-1600 \mathrm{~mL} ; 4 \mathrm{~mL} / \mathrm{min})$, and monitored at $254 \mathrm{~nm}$.

\subsection{Separation of the Components in the Partition Precipitate of MeOH Extract by Pre-HPLC}

The partition precipitate of the MeOH extract was separated using the same pre-HPLC and column as mentioned above. Briefly, $37.6 \mathrm{mg}$ of the sample was dissolved in $800 \mu \mathrm{L}$ of $75 \%$ DMSO aqueous solution and loaded for purification using $65 \% \mathrm{MeOH}(0-450 \mathrm{~mL})$ as the mobile phase and eluted at $4 \mathrm{~mL} / \mathrm{min}$. The elution was monitored at $254 \mathrm{~nm}$.

\subsection{Synthesis and Purification of Rosmarinic Acid Ethyl and Propyl Esters}

The ethyl and propyl rosmarinates were synthesized as described previously [34]. The $3 \mathrm{~A}$ molecular sieve was activated by heating at approximately $350^{\circ} \mathrm{C}$ for $3.5 \mathrm{~h}$ in a muffle furnace, and the Amberlite ${ }^{\circledR} \mathrm{IR}-120\left(\mathrm{H}^{+}\right.$form) acidic sulfonic resin was activated by heating at $110^{\circ} \mathrm{C}$ for $48 \mathrm{~h}$. The activated $3 \mathrm{~A}$ molecular sieve was individually mixed with ethanol and 1-propanol $(10 \% w / v)$ and allowed to stand for $48 \mathrm{~h}$ for solvent dehydration. Then, the anhydrous ethanol and 1-propanol (each $20 \mathrm{~mL}$ ) were individually mixed with the activated $3 \mathrm{~A}$ molecular sieve ( $3 \mathrm{~g})$, activated Amberlite ${ }^{\circledR}$ IR-120 acidic sulfonic resin $(1 \mathrm{~g})$, and rosmarinic acid $(100 \mathrm{mg})$ in sealed reagent bottles. The reaction mixtures were incubated at $55{ }^{\circ} \mathrm{C}$ in an orbital shaker (145 rpm), and the reaction solutions were continuously monitored using HPLC at $0,14,24,37$, and $72 \mathrm{~h}$. The HPLC samples were prepared by mixing $10 \mu \mathrm{L}$ of each reaction solution and $800 \mu \mathrm{L}$ of $\mathrm{MeOH}$, filtered $(0.45 \mu \mathrm{m}$; Whatman, Clifton, NJ, USA), and subjected to HPLC detection (injection volume $15 \mu \mathrm{L}$ ). All reactions were completed within $72 \mathrm{~h}$, and the reaction solutions were then centrifuged (Union 32R Plus centrifuge; Hanil Scientific Inc., Gimpo, Korea) for $30 \mathrm{~min}$ at $4000 \mathrm{rpm}(3720 \times g)$ and $25^{\circ} \mathrm{C}$. After centrifugation, each supernatant was further filtered $(0.45 \mu \mathrm{m}$ syringe filter $)$ and evaporated by rotary evaporation and a Genevac EZ-2 Plus evaporator (SP-Scientific, Gardiner, NY, USA), affording $73 \mathrm{mg}$ of ethyl rosmarinate and $80 \mathrm{mg}$ of propyl rosmarinate.

Further purification of the synthetic ethyl and propyl esters by HSCCC was carried out using $n$-hexane/EtOAc/MeOH/water (4:5:4:5, $v / v)$ as the solvent system, which offered suitable $K$ values for ethyl rosmarinate $(K=0.49)$ and propyl rosmarinate $(K=0.87)$. In brief, the HSCCC coil was filled with the upper layer of the solvent system as the stationary phase, and the rotation speed was then adjusted to $850 \mathrm{rpm}$. The lower layer of the solvent system was then introduced as the mobile phase at $4 \mathrm{~mL} / \mathrm{min}$ until a hydrodynamic equilibrium was achieved. Then, the sample solution $(15 \mathrm{~mL})$ was loaded to the sample loop, which was prepared by dissolving each sample (ethyl rosmarinate, $72 \mathrm{mg}$; propyl rosmarinate, $78 \mathrm{mg}$ ) in $15 \mathrm{~mL}$ of biphasic solvents composed of $7 \mathrm{~mL}$ of stationary phase and $8 \mathrm{~mL}$ of the mobile phase. The eluates were monitored at 210 and $280 \mathrm{~nm}$ for ethyl rosmarinate, and $280 \mathrm{~nm}$ for propyl rosmarinate. The elution speed of the mobile phase was $4 \mathrm{~mL} / \mathrm{min}$ for both of the HSCCC separations.

\subsection{HPLC Condition}

A Dionex system (Dionex, Sunnyvale, CA, USA) was used for HPLC analysis, which consisted of a P850 pump, an ASI-100 automated sample injector, an STH585 column oven (maintained at $30^{\circ} \mathrm{C}$ ), and a UVD170S detector. Acid water $(0.1 \%$ trifluoroacetic 
acid) (A) and $\mathrm{MeOH}$ (B) were used as the HPLC mobile phases. The L. meyenii samples were monitored at $254 \mathrm{~nm}$ and separated $(0.7 \mathrm{~mL} / \mathrm{min})$ using an Eclipse XDB-C18 column $(150 \times 4.6 \mathrm{~mm}, 5 \mu \mathrm{m})$ as follows: $10-100 \%$ B at $0-20 \mathrm{~min} ; 100 \%$ B at $20-24 \mathrm{~min} ; 100-10 \%$ B at 26-30 min; and the synthetic samples were monitored at 210 and $280 \mathrm{~nm}$ and separated using a Synergi Hydro-RP $80 \mathrm{~A}$ column $(150 \times 4.60 \mathrm{~mm}, 4 \mu \mathrm{m})$ as follows: $10-55 \% \mathrm{~B}$ at $0-5 \mathrm{~min} ; 55-100 \%$ B at $5-20 \mathrm{~min} ; 100-10 \%$ B at $20-25 \mathrm{~min} ; 10 \%$ B at $25-30 \mathrm{~min}$.

\subsection{Structure Identification}

The structural identification of the isolated natural compounds or synthetic compounds was performed using EI-MS (JEOL JMS-700; JEOL Ltd., Tokyo, Japan), an AB Sciex QTrap ${ }^{\circledR} 5500$ mass spectrometer (Foster City, CA, USA), $400 \mathrm{MHz}{ }^{1} \mathrm{H}-\mathrm{NMR}$ (JNMECZ400S/L1; JEOL Ltd., Japan), 600 MHz NMR (Bruker Avance Neo 600 Ultra Shield $^{\text {TM}}$; Bruker Biospin, Rheinstetten, Germany), and comparison with published papers and a standard compound (rosmarinic acid).

\subsection{Activity Assay}

\subsubsection{Antioxidant Assay}

The antioxidant potential of the samples was evaluated using DPPH radical scavenging assay, as reported previously [12]. In brief, $180 \mu \mathrm{L}$ of freshly prepared DPPH solution $(0.32 \mathrm{mM}$ in $\mathrm{MeOH}$ ) was mixed with $20 \mu \mathrm{L}$ of the sample (in $50 \% \mathrm{MeOH}$, extracts and fractions, $50-400 \mu \mathrm{g} / \mathrm{mL}$; components, $125-500 \mu \mathrm{M}$ ) in a 96-well plate and incubated for $20 \mathrm{~min}$ in the dark at $25^{\circ} \mathrm{C}$. Then, the absorbance $(570 \mathrm{~nm})$ of the reaction solution was measured using an EL800 microplate reader (Bio-Tek Instruments, Winooski, VT, USA). Quercetin was used as a positive control. The DPPH radical scavenging activity (\%) was calculated using Equation (1):

$$
\% \text { inhibition }=\left(1-\frac{A_{\text {sample }}-A_{\text {blank } 1}}{A_{\text {control }}-A_{\text {blank } 2}}\right) \times 100 \%
$$

where $A_{\text {sample }}$ is the absorbance of DPPH solution with the sample, $A_{\text {blank } 1}$ is the absorbance of the test sample without DPPH, $A_{\text {control }}$ is the absorbance of DPPH solution without sample, $A_{\text {blank } 2}$ is the absorbance of $\mathrm{MeOH}$, without DPPH or sample.

\subsubsection{AR Inhibition Assay}

The preparation of rat lens AR and AR inhibition assay were conducted as we previously reported [11]. The eyes of 10-week Sprague-Dawley rats (250-280 g) were removed and kept at $-70^{\circ} \mathrm{C}$ before use. Then, the lenses were removed from the eyes using surgical scissors and tweezers, ground in a mortar (precooled at $-70^{\circ} \mathrm{C}$ ) and extracted using $0.1 \mathrm{M}$ phosphate-buffered saline (PBS) of $\mathrm{pH} 6.2$ (approximately $0.5 \mathrm{~mL}$ of buffer per one rat lens). The extract solution was further centrifuged at $10,000 \times \mathrm{g}$ for $30 \mathrm{~min}$ at $4{ }^{\circ} \mathrm{C}$ (Mega $17 \mathrm{R}$, Hanil Science Industry, Gimpo, Korea), and the supernatant was collected and used as rat lens AR homogenate.

For AR inhibition assay, $100 \mu \mathrm{L}$ of $0.1 \mathrm{M}$ PBS ( $\mathrm{pH} 7.0$ ), $20 \mu \mathrm{L}$ of AR homogenate, $20 \mu \mathrm{L}$ of NADPH (cofactor, $2.4 \mathrm{mM}$ in $0.1 \mathrm{M}$ PBS of $\mathrm{pH}$ 8.0), $20 \mu \mathrm{L}$ of the sample (in a mixture of water and DMSO; extracts and fractions 62.5-100 $\mu \mathrm{g} / \mathrm{mL}$, compounds 3.9-500 $\mu \mathrm{M}$ ), and $20 \mu \mathrm{L}$ of ammonium sulfate solution (4 M in 0.1 M PBS of pH 7.0) were pipetted into a 96-well plate. Then, $20 \mu \mathrm{L}$ of the substrate (in $0.1 \mathrm{M}$ PBS of pH 7.0; $25 \mathrm{mM}$ of DL-glyceraldehyde dimmer) was added, and the absorbance $(340 \mathrm{~nm})$ was measured for 6 min using an Epoch microplate spectrophotometer (BioTek Instruments, Winooski, VT, USA). Quercetin was used as the positive control (final concentration 6.25-25 $\mu \mathrm{M}$ ) [23]. DMSO was used to prepare samples, but its ratio was kept within $0.5 \%(v / v)$ of the reaction system. The AR inhibition (\%) by samples was calculated using Equation (2):

$$
\% \text { inhibition }=\left(1-\frac{\mid \text { Slope }_{s}|-| \text { Slope }_{b} \mid}{\mid \text { Slope }_{c}|-| \text { Slope }_{b} \mid}\right) \times 100 \%
$$


where Slope S $_{\mathrm{S}} \mathrm{Slope}_{\mathrm{b}}$, and $\mathrm{Slope}_{\mathrm{c}}$ are the slopes derived from the OD340 nm (abscissa) versus the reaction time (min; ordinate) - dotted lines of sample group (with enzyme and sample), blank group (without enzyme or sample), and control group (with enzyme but without sample). | Slope| is the absolute value of the slope.

\subsection{Quantification of Rosmarinic Acid in the Extracts and Fractions of L. meyenii}

The contents of rosmarinic acid (3) in the extracts and fractions of L. meyenii were quantified using HPLC assay (injection volume $10 \mu \mathrm{L}$ ) as the condition described in Section 4.7. A stock solution of rosmarinic acid was prepared in $50 \% \mathrm{MeOH}$ at $2.00 \mathrm{mg} / \mathrm{mL}$ and then diluted to appropriate concentrations using $50 \% \mathrm{MeOH}$ to make a calibration curve and validate the HPLC method. The calibration curve was plotted with the HPLC peak areas as the $y$-axis and the concentrations of rosmarinic acid as the $x$-axis (triplicate, $0.39-400 \mu \mathrm{g} / \mathrm{mL}$ ). The limit of detection and limit of quantification were determined by signal-to-noise ratios of three $(\mathrm{S} / \mathrm{N}=3)$ and ten $(\mathrm{S} / \mathrm{N}=10)$, respectively. The precision of the quantification method was evaluated by measuring the relative standard deviation (RSD) values of the peak areas of rosmarinic acid $(12.5$ and $100 \mu \mathrm{g} / \mathrm{mL})$ determined by HPLC at intra-day $(n=6)$ and inter-day $(n=3)$. To examine the accuracy of the quantification method, a spike recovery test was carried out by mixing $0.20 \mathrm{~mL}$ of rosmarinic acid standard solutions (in $50 \% \mathrm{MeOH}, 25$ and $200 \mu \mathrm{g} / \mathrm{mL}$ ) individually with $0.20 \mathrm{~mL}$ of the $50 \% \mathrm{MeOH}$ extract solution (in $50 \% \mathrm{MeOH}, 100 \mu \mathrm{g} / \mathrm{mL}$ ). The peak areas of rosmarinic acid in the $50 \% \mathrm{MeOH}$ extract solution and the spiked solution were determined by HPLC assay (injection volume $10 \mu \mathrm{L}$, in triplicate) to calculate the concentrations of rosmarinic acid in the $50 \% \mathrm{MeOH}$ extract solution $\left(C_{1}\right)$ and the spiked solution $\left(C_{2}\right)$ using the plotted calibration curve, which were used to calculate the spike recovery using Equation (3):

$$
\% \text { Spike recovery }=\frac{C_{2} \times V_{2}-C_{1} \times V_{1}}{C_{0} \times V_{0}} \times 100 \%
$$

where $V_{0}$ and $V_{1}$ are the volumes of the standard solution $\left(V_{0}, 0.20 \mathrm{~mL}\right)$ and the $50 \%$ $\mathrm{MeOH}$ extract solution $\left(V_{1}, 0.20 \mathrm{~mL}\right)$ used for the spiking test, respectively, and $V_{2}$ is the volume of the spiked sample solution $\left(V_{2}, V_{2}=V_{0}+V_{1}=0.4 \mathrm{~mL}\right) ; C_{0}, C_{1}$, and $C_{2}$ are the concentrations of rosmarinic acid in the standard solution $\left(C_{0}, 25\right.$ and $\left.200 \mu \mathrm{g} / \mathrm{mL}\right)$, the $50 \%$ $\mathrm{MeOH}$ extract solution ( $C_{1}$, calculated), and the spiked solution $\left(C_{2}\right.$, calculated).

In addition to the $50 \% \mathrm{MeOH}$ extract solution, the other extracts and fractions of L. meyenii were also prepared as solutions (in $50 \% \mathrm{MeOH}, 100 \mu \mathrm{g} / \mathrm{mL}$ ) and determined by HPLC (injection volume $10 \mu \mathrm{L}$, in triplicate). The content $(\mathrm{mg} / \mathrm{g}$ ) of rosmarinic acid in each sample powder was calculated as the concentration of the rosmarinic acid in the sample solution (calculated from the calibration curve) divided by the concentration of the sample solution tested $(100 \mu \mathrm{g} / \mathrm{mL})$.

\subsection{Statistical Analysis}

All activity assays were performed in triplicate and the results were presented as mean \pm standard deviations (SDs). The half-maximal inhibitory concentrations ( $\mathrm{IC}_{50}$ values) of samples against DPPH radicals and AR were calculated via linear regression and logarithmic analysis, respectively. One-way ANOVA with Tukey's multiple comparisons test was used to compare the differences of the $\mathrm{IC}_{50}$ values of the active samples against DPPH radicals and AR, which were performed using GraphPad Prism (Version 8.4.2, GraphPad Software, San Diego, CA, USA), and $p<0.05$ was statistically significant. Moreover, the correlations of rosmarinic acid content $(\mathrm{mg} / \mathrm{g})$ and the activities of DPPH radical scavenging and AR inhibition in the extracts/fraction of L. meyenii were assessed by calculating Pearson's correlation coefficients with SPSS software (Version 25; IBM, New York, NY, USA). 


\section{Conclusions}

In conclusion, seven compounds were separated and identified from the $\mathrm{MeOH}$ and $50 \% \mathrm{MeOH}$ extracts of L. meyenii and their active fractions, namely, caffeic acid (1), hesperidin (2), rosmarinic acid (3), diosmin (4), methyl rosmarinate (5), diosmetin (6), and butyl rosmarinate (7). Among these, compounds 2, 4, 6, and 7 are reported in L. meyenii for the first time and 3, 5, and 7 possessed remarkable antioxidant and AR inhibitory activities. In particular, 3 is the key contributor to the antioxidant and AR inhibitory activities of L. meyenii, which was rich in the $\mathrm{MeOH}$ extract $(333.84 \mathrm{mg} / \mathrm{g}$ ) and $50 \% \mathrm{MeOH}$ extract $(135.41 \mathrm{mg} / \mathrm{g}$ ) of L. meyenii. It was especially abundant in the EtOAc and $n$-BuOH fractions $(373.71-804.07 \mathrm{mg} / \mathrm{g}$ ) of the $\mathrm{MeOH}$ and $50 \% \mathrm{MeOH}$ extracts. Moreover, comparative study of rosmarinic acid and its short-chain esters $(\leq \mathrm{C} 4)$ revealed that esterification of rosmarinic acid using short-chain primary alcohols $(\leq \mathrm{C} 4)$ can significantly increase its antioxidant and AR inhibitory potential. In addition, the HSCCC separation method established in this study can be used for preparative separation of rosmarinic acid from L. meyenii and other natural products.

Supplementary Materials: The following are available online at https:/ /www.mdpi.com/article/10 $.3390 /$ plants10122773/s1, Table S1: 1H-NMR data of rosmarinic acid derivatives from L. meyenii and chemical esterification ( $\delta$ in ppm, J in Hz), Table S2: NMR data of compounds 2, 4, and 6 isolated from L. meyenii, Table S3: Calibration curve, detection/quantification limits, and precision of rosmarinic acid, Table S4: The recovery rate of rosmarinic acid in spike recovery test, Figure S1: Chemical synthesis and HSCCC purification of ethyl rosmarinate, Figure S2: Chemical synthesis and HSCCC purification of propyl rosmarinate, Figures S3-S9: NMR and ESI-MS/MS spectroscopy of the separated compounds 1-7 from L. meyenii, Figures S10 and S11: 1H-NMR (400 MHz, MeOH- $\left.d_{4}\right)$ spectroscopy of synthesized ethyl and propyl rosmarinates.

Author Contributions: Conceptualization, G.Z. and S.S.L.; methodology, G.Z. and H.Y.K.; software, G.Z.; validation, H.Y.K. and K.H.K.; formal analysis, G.Z. and K.-H.J.; investigation, G.Z. and K.-O.S.; resources, Y.N.G.Q., P.H.G.A. and S.S.L.; data curation, G.Z. and S.S.L.; writing-original draft preparation, G.Z.; writing-review and editing, G.Z. and S.S.L.; visualization, G.Z., K.-H.J. and Y.N.G.Q.; supervision, S.S.L.; project administration, S.S.L.; funding acquisition, S.S.L. All authors have read and agreed to the published version of the manuscript.

Funding: This research was supported by Basic Science Research Program through the National Research Foundation of Korea (NRF) funded by the Ministry of Education (2018R1D1A1A09081945) and supported by the National Research Foundation of Korea (NRF) grant funded by the Korea government (MSIT) (No. 2021R1A2C1005246).

Institutional Review Board Statement: The study was conducted according to the guidelines of the Declaration of Helsinki, and approved by the Ethics Committee of Hallym University (Hallym-2016-95).

Informed Consent Statement: Not applicable.

Data Availability Statement: Data is contained within the article or Supplementary Data.

Acknowledgments: The authors would like to thank Soo Kyeong Lee for her administrative support.

Conflicts of Interest: The authors declare no conflict of interest.

\section{References}

1. Saeedi, P.; Petersohn, I.; Salpea, P.; Malanda, B.; Karuranga, S.; Unwin, N.; Colagiuri, S.; Guariguata, L.; Motala, A.A.; Ogurtsova, K. Global and regional diabetes prevalence estimates for 2019 and projections for 2030 and 2045: Results from the International Diabetes Federation Diabetes Atlas. Diabetes Res. Clin. Pract. 2019, 157, 107843. [CrossRef]

2. Araki, E.; Nishikawa, T. Oxidative stress: A cause and therapeutic target of diabetic complications. J. Diabetes Investig. 2010, 1, 90-96. [CrossRef] [PubMed]

3. Maccari, R.; Ottanà, R. Targeting aldose reductase for the treatment of diabetes complications and inflammatory diseases: New insights and future directions. J. Med. Chem. 2015, 58, 2047-2067. [CrossRef]

4. Yan, L.J. Redox imbalance stress in diabetes mellitus: Role of the polyol pathway. Anim. Models Exp. Med. 2018, 1, 7-13. [CrossRef] [PubMed]

5. Giacco, F.; Brownlee, M. Oxidative stress and diabetic complications. Circ. Res. 2010, 107, 1058-1070. [CrossRef] [PubMed] 
6. Burgos-Morón, E.; Abad-Jiménez, Z.; Martinez de Maranon, A.; Iannantuoni, F.; Escribano-López, I.; López-Domènech, S.; Salom, C.; Jover, A.; Mora, V.; Roldan, I. Relationship between oxidative stress, ER stress, and inflammation in type 2 diabetes: The battle continues. J. Clin. Med. 2019, 8, 1385. [CrossRef] [PubMed]

7. Plants of the World Online. Lepechinia Meyenii (Walp.) Epling. Available online: http://www.plantsoftheworldonline.org/ taxon/urn:lsid:ipni.org:names:449276-1 (accessed on 20 November 2021).

8. De Feo, V.; Soria, R.M.U. Medicinal plants and phytotherapy in traditional medicine of Paruro Province, Cusco Department, Peru. Pharmacologyonline 2012, 1, 154-219.

9. Hammond, G.B.; Fernández, I.D.; Villegas, L.F.; Vaisberg, A.J. A survey of traditional medicinal plants from the Callejón de Huaylas, Department of Ancash, Perú. J. Ethnopharmacol. 1998, 61, 17-30. [CrossRef]

10. de la Cruz, M.G.; Malpartida, S.B.; Santiago, H.B.; Jullian, V.; Bourdy, G. Hot and cold: Medicinal plant uses in Quechua speaking communities in the high Andes (Callejón de Huaylas, Ancash, Perú). J. Ethnopharmacol. 2014, 155, 1093-1117. [CrossRef]

11. Zuo, G.L.; Kim, H.Y.; Guillen Quispe, Y.N.; Wang, Z.Q.; Hwang, S.H.; Shin, K.O.; Lim, S.S. Efficient separation of phytochemicals from Muehlenbeckia volcanica (Benth.) Endl. by polarity-stepwise elution counter-current chromatography and their antioxidant, antiglycation, and aldose reductase inhibition potentials. Molecules 2021, 26, 224. [CrossRef]

12. Zuo, G.; Kim, H.Y.; Guillen Quispe, Y.N.; Wang, Z.; Kim, K.H.; Gonzales Arce, P.H.; Lim, S.S. Valeriana rigida Ruiz \& Pav. Root Extract: A New Source of Caffeoylquinic Acids with Antioxidant and Aldose Reductase Inhibitory Activities. Foods 2021, 10, 1079.

13. Wang, Z.; Wu, Z.; Zuo, G.; Lim, S.S.; Yan, H. Defatted Seeds of Oenothera biennis as a Potential Functional Food Ingredient for Diabetes. Foods 2021, 10, 538. [CrossRef] [PubMed]

14. Wang, Z.; Quispe, Y.N.G.; Hwang, S.H.; Zuo, G.; Lim, S.S. Pistafolin B is the major aldose reductase inhibitor of the pods of tara [Caesalpinia spinose (Molina) Kuntze]. Ind. Crop. Prod. 2018, 122, 709-715. [CrossRef]

15. Wang, Z.; Hwang, S.H.; Quispe, Y.N.G.; Arce, P.H.G.; Lim, S.S. Investigation of the antioxidant and aldose reductase inhibitory activities of extracts from Peruvian tea plant infusions. Food Chem. 2017, 231, 222-230. [CrossRef] [PubMed]

16. Crespo, M.I.; Chabán, M.F.; Lanza, P.A.; Joray, M.B.; Palacios, S.M.; Vera, D.M.A.; Carpinella, M.C. Inhibitory effects of compounds isolated from Lepechinia meyenii on tyrosinase. Food Chem. Toxicol. 2019, 125, 383-391. [CrossRef] [PubMed]

17. Chabán, M.F.; Karagianni, C.; Joray, M.B.; Toumpa, D.; Sola, C.; Crespo, M.I.; Palacios, S.M.; Athanassopoulos, C.M.; Carpinella, M.C. Antibacterial effects of extracts obtained from plants of Argentina: Bioguided isolation of compounds from the anti-infectious medicinal plant Lepechinia meyenii. J. Ethnopharmacol. 2019, 239, 111930. [CrossRef]

18. Gong, Y.; Huang, X.-Y.; Pei, D.; Duan, W.-D.; Zhang, X.; Sun, X.; Di, D.-L. The applicability of high-speed counter current chromatography to the separation of natural antioxidants. J. Chromatogr. A 2020, 1623, 461150. [CrossRef] [PubMed]

19. Yoon, K.D.; Chin, Y.-W.; Yang, M.H.; Kim, J. Separation of anti-ulcer flavonoids from Artemisia extracts by high-speed countercurrent chromatography. Food Chem. 2011, 129, 679-683. [CrossRef]

20. Pan, Z.H.; Ning, D.S.; Fu, Y.X.; Li, D.P.; Zou, Z.Q.; Xie, Y.C.; Yu, L.L.; Li, L.C. Preparative isolation of piceatannol derivatives from Passion fruit (Passiflora edulis) seeds by high-speed countercurrent chromatography combined with high-performance liquid chromatography and screening for $\alpha$-Glucosidase inhibitory activities. J. Agric. Food Chem. 2020, 68, 1555-1562. [CrossRef]

21. Wang, X.; Zuo, G.L.; Wang, C.Y.; Kim, H.Y.; Lim, S.S.; Tong, S.Q. An Off-Line DPPH-GC-MS Coupling Countercurrent Chromatography Method for Screening, Identification, and Separation of Antioxidant Compounds in Essential Oil. Antioxidants 2020, 9, 702. [CrossRef]

22. Ito, Y. Golden rules and pitfalls in selecting optimum conditions for high-speed counter-current chromatography. J. Chromatogr. A 2005, 1065, 145-168. [CrossRef] [PubMed]

23. Lu, Q.; Hao, M.; Wu, W.; Zhang, N.; Isaac, A.T.; Yin, J.; Zhu, X.; Du, L.; Yin, X. Antidiabetic cataract effects of GbE, rutin and quercetin are mediated by the inhibition of oxidative stress and polyol pathway. Acta Biochim. Pol. 2018, 65, 35-41. [CrossRef]

24. Xu, D.; Hu, M.J.; Wang, Y.Q.; Cui, Y.L. Antioxidant activities of quercetin and its complexes for medicinal application. Molecules 2019, 24, 1123. [CrossRef] [PubMed]

25. Wang, C.; Zuo, G.; Wang, X.; Kim, H.Y.; Zhao, S.; Sun, W.; Tong, S.; Lim, S.S. Retention mechanism of pH-peak-focusing in countercurrent chromatographic separation of baicalin and wogonoside from Scutellaria baicalensis Georgi. J. Sep. Sci. 2020, 43, 3806-3815. [CrossRef]

26. Yang, Z.; Guo, P.; Han, R.; Wu, D.; Gao, J.-M.; Wu, S. Methanol linear gradient counter-current chromatography for the separation of natural products: Sinopodophyllum hexandrum as samples. J. Chromatogr. A 2019, 1603, 251-261. [CrossRef] [PubMed]

27. Song, X.; Li, K.; Cui, L.; Yu, J.; Ali, I.; Zhu, H.; Wang, Q.; Wang, X.; Wang, D. A simple and efficient linear gradient coupled with inner-recycling high-speed counter-current chromatography mode for the preparative separation of flavonoid glycosides from leaves of custard apple. J. Chromatogr. A 2020, 1615, 460719. [CrossRef]

28. Du, Q.; Jerz, G.; Chen, P.; Winterhalter, P. Preparation of ursane triterpenoids from Centella asiatica using high speed countercurrent chromatography with step-gradient elution. J. Liq. Chromatogr. Relat. Technol. 2004, 27, 2201-2215. [CrossRef]

29. Razali, N.; Junit, S.M.; Ariffin, A.; Ramli, N.S.F.; Aziz, A.A. Polyphenols from the extract and fraction of T. indica seeds protected HepG2 cells against oxidative stress. BMC Complement. Altern. Med. 2015, 15, 438. [CrossRef]

30. Ćirić, A.; Prosen, H.; Jelikić-Stankov, M.; Đurđević, P. Evaluation of matrix effect in determination of some bioflavonoids in food samples by LC-MS/MS method. Talanta 2012, 99, 780-790. [CrossRef]

31. Cheigh, C.-I.; Chung, E.-Y.; Chung, M.S. Enhanced extraction of flavanones hesperidin and narirutin from Citrus unshiu peel using subcritical water. J. Food Eng. 2012, 110, 472-477. [CrossRef] 
32. Nizamutdinova, I.T.; Jeong, J.J.; Xu, G.H.; Lee, S.H.; Kang, S.S.; Kim, Y.S.; Chang, K.C.; Kim, H.J. Hesperidin, hesperidin methyl chalone and phellopterin from Poncirus trifoliata (Rutaceae) differentially regulate the expression of adhesion molecules in tumor necrosis factor- $\alpha$-stimulated human umbilical vein endothelial cells. Int. Immunopharmacol. 2008, 8, 670-678. [CrossRef]

33. Nieto, J.; Gutierrez, A. ${ }^{1} \mathrm{H}$ NMR spectra at $360 \mathrm{MHz}$ of diosmin and hesperidin in DMSO solution. Spectr. Lett. 1986, 19, 427-434. [CrossRef]

34. Lecomte, J.; Giraldo, L.J.L.; Laguerre, M.; Baréa, B.; Villeneuve, P. Synthesis, characterization and free radical scavenging properties of rosmarinic acid fatty esters. J. Am. Oil Chem. Soc. 2010, 87, 615-620. [CrossRef]

35. Chen, X.; Xu, L.; Guo, S.; Wang, Z.; Jiang, L.; Wang, F.; Zhang, J.; Liu, B. Profiling and comparison of the metabolites of diosmetin and diosmin in rat urine, plasma and feces using UHPLC-LTQ-Orbitrap MSn. J. Chromatogr. B 2019, 1124, 58-71. [CrossRef]

36. So, Y.; Lee, S.Y.; Han, A.-R.; Kim, J.B.; Jeong, H.G.; Jin, C.H. Rosmarinic acid methyl ester inhibits LPS-induced NO production via suppression of MyD88-dependent and-independent pathways and induction of HO-1 in RAW 264.7 cells. Molecules 2016, 21, 1083. [CrossRef] [PubMed]

37. Yan, Y.; Liu, X.; Gao, J.; Wu, Y.; Li, Y. Inhibition of TGF- $\beta$ Signaling in Gliomas by the Flavonoid Diosmetin Isolated from Dracocephalum peregrinum L. Molecules 2020, 25, 192. [CrossRef] [PubMed]

38. Wang, H.; Provan, G.J.; Helliwell, K. Determination of rosmarinic acid and caffeic acid in aromatic herbs by HPLC. Food Chem. 2004, 87, 307-311. [CrossRef]

39. Serrano, C.A.; Villena, G.K.; Rodríguez, E.F. Phytochemical profile and rosmarinic acid purification from two Peruvian Lepechinia Willd. species (Salviinae, Mentheae, Lamiaceae). Sci. Rep. 2021, 11, 7260. [CrossRef]

40. Jain, D.; Bansal, M.K.; Dalvi, R.; Upganlawar, A.; Somani, R. Protective effect of diosmin against diabetic neuropathy in experimental rats. J. Integr. Med. 2014, 12, 35-41. [CrossRef]

41. Homayouni, F.; Haidari, F.; Hedayati, M.; Zakerkish, M.; Ahmadi, K. Blood pressure lowering and anti-inflammatory effects of hesperidin in type 2 diabetes; a randomized double-blind controlled clinical trial. Phytother. Res. 2018, 32, 1073-1079. [CrossRef]

42. Pari, L.; Srinivasan, S. Antihyperglycemic effect of diosmin on hepatic key enzymes of carbohydrate metabolism in streptozotocinnicotinamide-induced diabetic rats. Biomed. Pharmacother. 2010, 64, 477-481. [CrossRef]

43. Ahmed, S.; Mundhe, N.; Borgohain, M.; Chowdhury, L.; Kwatra, M.; Bolshette, N.; Ahmed, A.; Lahkar, M. Diosmin modulates the NF-kB signal transduction pathways and downregulation of various oxidative stress markers in alloxan-induced diabetic nephropathy. Inflammation 2016, 39, 1783-1797. [CrossRef] [PubMed]

44. Gong, X.; Xiong, L.; Bi, C.; Zhang, B. Diosmetin ameliorate type 2 diabetic mellitus by up-regulating Corynebacterium glutamicum to regulate IRS/PI3K/AKT-mediated glucose metabolism disorder in KK-Ay mice. Phytomedicine 2021, 87, 153582. [CrossRef]

45. Bayrasy, C.; Chabi, B.; Laguerre, M.; Lecomte, J.; Jublanc, É.; Villeneuve, P.; Wrutniak-Cabello, C.; Cabello, G. Boosting antioxidants by lipophilization: A strategy to increase cell uptake and target mitochondria. Pharm. Res. 2013, 30, 1979-1989. [CrossRef]

46. Blažević, T.; Reznicek, G.; Ding, L.; Yang, G.; Haiss, P.; Heiss, E.H.; Dirsch, V.M.; Liu, R. Short Chain ( $\leq$ C4) Esterification Increases Bioavailability of Rosmarinic Acid and Its Potency to Inhibit Vascular Smooth Muscle Cell Proliferation. Front. Pharmacol. 2021, 11, 2355. [CrossRef]

47. Kang, J.; Tang, Y.; Liu, Q.; Guo, N.; Zhang, J.; Xiao, Z.; Chen, R.; Shen, Z. Isolation, modification, and aldose reductase inhibitory activity of rosmarinic acid derivatives from the roots of Salvia grandifolia. Fitoterapia 2016, 112, 197-204. [CrossRef] [PubMed]

48. Shen, Y.H.; Wang, L.Y.; Zhang, B.B.; Hu, Q.M.; Wang, P.; He, B.Q.; Bao, G.H.; Liang, J.Y.; Wu, F.H. Ethyl rosmarinate protects high glucose-induced injury in human endothelial cells. Molecules 2018, 23, 3372. [CrossRef]

49. Chen, J.; Wang, F.; Lee, F.S.C.; Wang, X.; Xie, M. Separation and identification of water-soluble salvianolic acids from Salvia miltiorrhiza Bunge by high-speed counter-current chromatography and ESI-MS analysis. Talanta 2006, 69, 172-179. [CrossRef]

50. Xie, Z.; Liang, Z.; Xie, C.; Zhao, M.; Yu, X.; Yang, M.; Huang, J.; Xu, X. Separation and purification of rosmarinic acid and rutin from Glechoma hederacea L. using high-speed counter-current chromatography. Sep. Sci. Technol. 2014, 49, 588-593. [CrossRef]

51. Kwon, S.H.; Wang, Z.; Hwang, S.H.; Kang, Y.H.; Lee, J.Y.; Lim, S.S. Comprehensive evaluation of the antioxidant capacity of Perilla frutescens leaves extract and isolation of free radical scavengers using step-wise HSCCC guided by DPPH-HPLC. Int. J. Food Prop. 2017, 20, 921-934. [CrossRef]

52. Zhu, C.; Niu, H.; Nie, A.; Bian, M. Bioactivity-guided separation of potential $\alpha$-glycosidase inhibitor from clerodendranthus spicatus based on HSCCC coupled with molecular docking. Sci. Rep. 2021, 11, 6914. [CrossRef] [PubMed]

53. Zuo, G.; Wang, Z.; Quispe, Y.N.G.; Hwang, S.H.; Kim, H.Y.; Kang, B.G.; Lim, S.S. Target guided isolation of potential tyrosinase inhibitors from Otholobium pubescens (Poir.) JW Grimes by ultrafiltration, high-speed countercurrent chromatography and preparative HPLC. Ind. Crop. Prod. 2019, 134, 195-205. [CrossRef] 